\title{
Particulate Organic Carbon Export Fluxes in the Canada Basin and Bering Sea as Derived from ${ }^{234} \mathrm{Th} /{ }^{238} \mathrm{U}$ Disequilibria
}

\author{
MIN CHEN, ${ }^{1,2}$ YIPU HUANG, ${ }^{1}$ PINGHE CAI ${ }^{1}$ and LAODONG GUO ${ }^{3}$
}

(Received 8 January 2002; accepted in revised form 22 May 2002)

\begin{abstract}
Seawater samples were collected in the water column of the Canada Basin and the Bering Sea from aboard the $\mathrm{R} / \mathrm{V}$ Xue Long during August 1999. Activity concentrations of dissolved and particulate ${ }^{234} \mathrm{Th}$ were measured using beta counting techniques to quantify the scavenging and residence time of ${ }^{234} \mathrm{Th}$ and organic carbon export fluxes. Primary production (PP) and bacterial production were also determined in the study areas through in situ incubation experiments. Significant ${ }^{234} \mathrm{Th}$ scavenging was observed in the upper $100 \mathrm{~m}$ of the water column in both study areas, with up to $40 \%$ of ${ }^{234} \mathrm{Th}$ deficit found at Bering Sea stations and $\sim 15 \%$ of ${ }^{234} \mathrm{Th}$ deficit at the Canada Basin station. Measured PP decreased from $\sim 12.5 \mu \mathrm{mol} \mathrm{C} / \mathrm{m}^{3} / \mathrm{h}$ in surface water to near zero at $\sim 100 \mathrm{~m}$ depth, with an integrated PP of $3.83 \mathrm{mmol} \mathrm{C} / \mathrm{m}^{2} / \mathrm{d}$ in the Canada Basin. Bacterial production, on the other hand, was on the order of $2.0 \mathrm{mmol} \mathrm{C} / \mathrm{m}^{2} / \mathrm{d}$, which is up to $52 \%$ of the integrated PP. Particulate organic carbon (POC) export fluxes derived from ${ }^{234} \mathrm{Th} /{ }^{238} \mathrm{U}$ disequilibrium were $\sim 1 \mathrm{mmol} \mathrm{C} / \mathrm{m}^{2} / \mathrm{d}$ in the Canada Basin and $\sim 10 \mathrm{mmol} \mathrm{C} / \mathrm{m}^{2} / \mathrm{d}$ in the Bering Sea, with fluxes in the latter area being 5 to 10 times higher than those found in the Canada Basin. These export fluxes correspond to a ThE ratio (the ratio of ${ }^{234} \mathrm{Th}$-derived POC export to primary production) of 0.26 for the Canada Basin and 0.7 for the Bering Sea. The higher ThE ratios in the study areas suggest a decoupling of production and particulate export in the high-latitude ocean. Ratios of POC to particulate ${ }^{234} \mathrm{Th}(\mu \mathrm{mol} \mathrm{C} / \mathrm{dpm})$ decreased consistently with increasing depth, suggesting that organic carbon is preferentially remineralized relative to ${ }^{234} \mathrm{Th}$. Interestingly, the profile of particulate ${ }^{234} \mathrm{Th}$ in the Canada Basin showed a unique characteristic: particulate ${ }^{234} \mathrm{Th}$ activities increased with increasing depth, suggesting a continuous scavenging of ${ }^{234} \mathrm{Th}$ and a rapid settling rate of the particles.
\end{abstract}

Key words: POC export flux, ${ }^{234} \mathrm{Th} /{ }^{238} \mathrm{U}$ disequilibrium, primary production, bacterial production, the Canada Basin, the Bering Sea

RÉSUMÉ. Au cours du mois d'août 1999, on a prélevé des échantillons d'eau de mer dans la colonne d'eau du bassin Canada et de la mer de Béring depuis le vaisseau RV Xue-Long. L'activité volumique du ${ }^{234} \mathrm{Th}$ dissous et particulaire a été mesurée à l'aide de techniques de comptage au rayonnement bêta afin de quantifier le temps de balayage et le temps de séjour du ${ }^{234} \mathrm{Th}$ et les flux d'exportation du carbone organique. On a aussi établi la production primaire (PP) et la production bactérienne dans les zones d'étude en réalisant des expériences d'incubation in situ. Dans les deux zones d'étude, on a observé un balayage marqué du ${ }^{234} \mathrm{Th}$ dans les $100 \mathrm{~m}$ supérieurs de la colonne d'eau, avec jusqu'à $40 \mathrm{p}$. cent de déficit de ${ }^{234} \mathrm{Th}$ aux postes de la mer de Béring et environ $15 \mathrm{p}$. cent au poste du bassin Canada. La PP mesurée baissait d'environ $12,5 \mu \mathrm{mol} \mathrm{C} / \mathrm{m}^{3} / \mathrm{h}$ dans l'eau de surface à près de zéro à environ $100 \mathrm{~m}$ de profondeur, avec une PP intégrée de $3,83 \mathrm{mmol} \mathrm{C} / \mathrm{m}^{2} / \mathrm{j}$ dans le bassin Canada. D' autre part, la production bactérienne était de l'ordre de $2,0 \mathrm{mmol} \mathrm{C} / \mathrm{m}^{2} / \mathrm{j}$, ce qui représente jusqu'à $52 \mathrm{p}$. cent de la PP intégrée. Les flux d'exportation du carbone organique particulaire (COP) calculés à partir du déséquilibre ${ }^{234} \mathrm{Th} /{ }^{238} \mathrm{U}$ étaient d'environ $1 \mathrm{mmol} \mathrm{C} / \mathrm{m}^{2} / \mathrm{j}$ dans le bassin Canada et d'environ $10 \mathrm{mmol} \mathrm{C} / \mathrm{m}^{2} / \mathrm{j}$ dans la mer de Béring, les flux dans cette région étant de 5 à 10 fois plus élevés que ceux trouvés dans le bassin Canada. Ces flux d'exportation correspondent à un rapport ThE (le rapport de l'exportation du COP dérivé $\mathrm{du}^{234} \mathrm{Th}$ à la production primaire) de 0,26 pour le bassin Canada et de 0,7 pour la mer de Béring. Les rapports plus élevés de ThE dans les zones d'étude suggèrent un découplage de la production et de l'exportation de particules dans l'océan septentrional. Les rapports de $\mathrm{COP}$ au ${ }^{234} \mathrm{Th}$ particulaire ( $\mu \mathrm{mol} \mathrm{C} / \mathrm{dpm}$ ) diminuaient de façon uniforme avec l'augmentation de la profondeur, ce qui suggère que le carbone organique est reminéralisé préférentiellement par rapport au ${ }^{234} \mathrm{Th}$. Il est à noter que le profil du ${ }^{234} \mathrm{Th}$ particulaire dans le bassin Canada affichait une caractéristique unique: l'activité du ${ }^{234} \mathrm{Th}$ particulaire augmentait avec la profondeur, ce qui suggère un balayage continu du ${ }^{234} \mathrm{Th}$ et un taux rapide de sédimentation des particules.

Mots clés: flux d'exportation du COP, déséquilibre ${ }^{234} \mathrm{Th} /{ }^{238} \mathrm{U}$, production primaire, production bactérienne, bassin Canada, mer de Béring

Traduit pour la revue Arctic par Nésida Loyer.

\footnotetext{
${ }^{1}$ Department of Oceanography, Xiamen University, Xiamen, 361005, China

${ }^{2}$ Corresponding author: mchen@jingxian.xmu.edu.cn

${ }^{3}$ International Arctic Research Center, University of Alaska Fairbanks, Fairbanks, Alaska 99775, U.S.A.

(c) The Arctic Institute of North America
} 


\section{INTRODUCTION}

Recent dramatic environmental changes seen in the Arctic Ocean and the surrounding areas may have profound impacts on the ecosystem and carbon fluxes (Manabe and Stouffer, 1993; Cuffey et al., 1995). One interesting aspect relates to the Arctic Ocean's important role as a region for $\mathrm{CO}_{2}$ sequestration through biological processes of carbon uptake, which can counteract greenhouse gas accumulation in the atmosphere. The question of the role of the Arctic Ocean in $\mathrm{CO}_{2}$ sequestration has often been approached with studies on new production or export production (Jenkins and Wallace, 1992; Buesseler, 1998), considered as the fraction of primary production that can be exported from the euphotic zone to the deep ocean. Estimates of polar biological production are now being revised; the polar area is suspected to be either more productive (Smith et al., 1991; Wheeler et al., 1996) or less productive than previously thought (Codispoti et al., 1991). The Arctic Ocean, in particular, has been considered among the most oligotrophic regions of the ocean because of its persistent ice cover and long, cold winter (polar night). However, recent estimates revealed that, at least in some sampling seasons, the Arctic Ocean and its adjacent seas could have relatively high production rates or high particulate organic carbon (POC) export fluxes (Longhurst et al., 1995; Moran et al., 1997). Nevertheless, the quantitative importance of biological production and organic carbon export fluxes in the Arctic Ocean and its surrounding regions is still poorly understood.

${ }^{234} \mathrm{Th}$, a particle-reactive radionuclide, is produced continuously in seawater from its highly soluble parent nuclide, ${ }^{238} \mathrm{U}$. Given its unique chemistry and appropriate half-life, ${ }^{234} \mathrm{Th}$ has become a valuable tracer for studying particle dynamics in the upper ocean over time scales of days to months (Buesseler et al., 1992; Charette and Moran, 1999). It has been used extensively to estimate the POC flux in many interdisciplinary research programs. Examples are the Equatorial Pacific Process Study (EqPac) (Buesseler et al., 1995; Murray et al., 1996; Bacon et al., 1996); the North Atlantic Bloom Experiment (NABE) (Buesseler et al., 1992; Cochran et al., 1995); the Arabian Sea Process Study (ASPS)(Buesseler et al., 1998); and the Antarctic Environment and Southern Ocean Process Study (AES-OPS)(Buesseler et al., 2001). Despite the wide application of ${ }^{234} \mathrm{Th}$, studies using ${ }^{234} \mathrm{Th} /{ }^{238} \mathrm{U}$ disequilibrium techniques on organic carbon export fluxes and biological production in the Arctic Ocean and surrounding regions are still very limited, largely because of sampling constraints imposed by extreme weather conditions.

Bacon et al. (1989) first determined particulate ${ }^{234} \mathrm{Th}$ activities at a station located near the Alpha Ridge and suggested that the scavenging of reactive species could be significantly lower in the Arctic Ocean than in other oceans. Cochran et al. (1995) reported water-column deficits of ${ }^{234} \mathrm{Th}$ relative to ${ }^{238} \mathrm{U}$ within a seasonally ice-free area over the northeast Greenland continental shelf and used these results to quantify rates of scavenging and POC export. Moran et al. $(1996,1997)$ determined dissolved and particulate ${ }^{234} \mathrm{Th}$ activities in the western Arctic and suggested that particle export occurred in the upper Arctic Ocean. Moran and Smith (2000) provided evidence of a marked spatial variability in POC export in the Beaufort Sea from ${ }^{234} \mathrm{Th}$ measurements. Very recently, Coppola et al. (2002) also used ${ }^{234} \mathrm{Th}$ as a tracer to estimate POC fluxes and further compared their estimates with POC fluxes measured by sediment traps in the Barents Sea.

In the present study, we measured dissolved and particulate ${ }^{234} \mathrm{Th}$ in the water column at four stations, one in the Canada Basin and three in the Bering Sea, and quantified scavenging residence times and fluxes of dissolved and particulate ${ }^{234} \mathrm{Th}$. We determined primary and bacterial production in the study areas and estimated the POC export fluxes in both the Canada Basin and the Bering Sea. To our knowledge, these are the first ${ }^{234} \mathrm{Th}$ data reported for the Bering Sea. Our results showed that ${ }^{234} \mathrm{Th} /$ ${ }^{238} \mathrm{U}$ disequilibrium occurred in both study areas, reflecting particle export on a monthly scale, but the POC export fluxes derived from the ${ }^{234} \mathrm{Th} /{ }^{238} \mathrm{U}$ disequilibrium in the Canada Basin were lower than those in the Bering Sea.

\section{METHODS}

\section{Sample Collection}

In August 1999, from onboard the R/V Xue Long, we collected water samples at four stations, one (C34) in the Canada Basin and three (B50, B51, and B52) in the Bering Sea (Fig. 1). Water depth was over $1000 \mathrm{~m}$ at all stations. Seawater was collected from seven depths $(1,10,25,50$, 75,100 , and $200 \mathrm{~m}$ ) for measurements of nutrients, POC, dissolved and particulate ${ }^{234} \mathrm{Th}$. For each sample, $30 \mathrm{~L}$ of seawater was collected using three $10 \mathrm{~L}$ Niskin bottles. Twenty-liter subsamples were used for dissolved and particulate ${ }^{234} \mathrm{Th}$ analysis. Aliquots of water samples were also collected for nutrients and POC measurements. Upon recovery, subsamples $(20 \mathrm{~L})$ for ${ }^{234} \mathrm{Th}$ determination were drained into Cubitainer ${ }^{\mathrm{TM}}$ collapsible containers, pressurized with compressed air, and passed through a $0.45 \mu \mathrm{m}$ membrane filter $(142 \mathrm{~mm})$. Filtrates were collected in 20 liter Cubitainers ${ }^{\mathrm{TM}}$ and acidified with $40 \mathrm{ml}$ concentrated $\mathrm{HCl}$. Filters were rinsed with $\sim 100 \mathrm{ml}$ of distilled water and then folded and stored frozen until analysis onboard.

\section{${ }^{234}$ Th Analyses}

After acidification, about $10 \mathrm{dpm}$ of ${ }^{228} \mathrm{Th}$ yield tracer and $60 \mathrm{mg}$ of $\mathrm{Fe}$ carrier (as $\mathrm{FeCl}_{3}$ ) were added to each dissolved sample. The samples were thoroughly mixed by bubbling with nitrogen for $10 \mathrm{~min}$, and then stood $\sim 6 \mathrm{~h}$ for the spike to equilibrate with the samples. About $40 \mathrm{ml}$ of concentrated $\mathrm{NH}_{4} \mathrm{OH}$ was added to precipitate $\mathrm{Fe}(\mathrm{OH})_{3}$, which co-precipitates with Th. The sample was stirred for $20 \mathrm{~min}$, then 


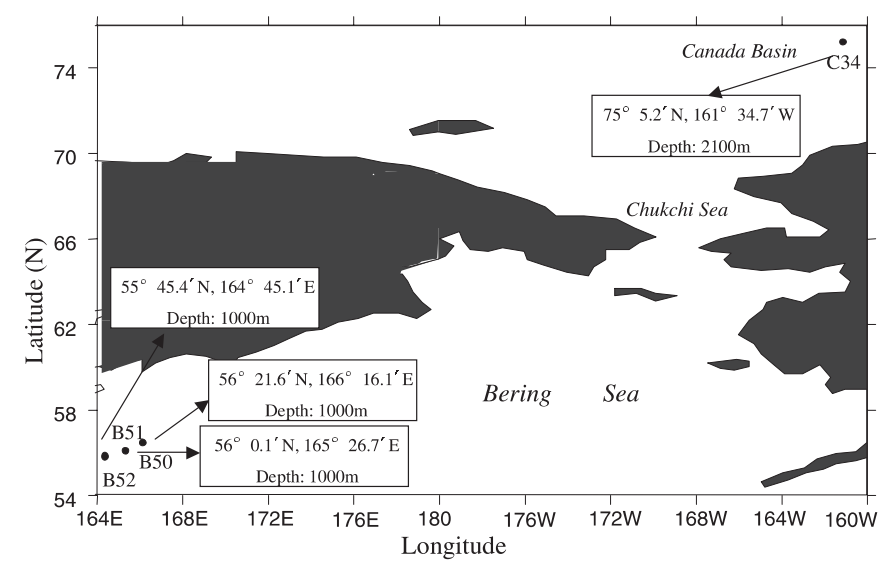

FIG. 1. Sampling locations in the Canada Basin and the Bering Sea.

allowed to settle. The precipitate was separated from the supernatant by centrifugation. The resultant $\mathrm{Fe}(\mathrm{OH})_{3}$ was re-dissolved in concentrated $\mathrm{HCl}$ to make a $9 \mathrm{~mol} / \mathrm{L} \mathrm{HCl}$ solution for further column chromatography work.

Detailed procedures of Th separation and purification are described in Chen et al. (1997) and Cai et al. (2002). Briefly, separation of $U$ and Th was accomplished by passing the solution through a chloride-form anion resin column, preconditioned with $9 \mathrm{~mol} / \mathrm{L} \mathrm{HCl}$. For Th purification, the effluent and rinses containing the Th fraction were taken to dryness, dissolved in $40 \mathrm{ml} 8 \mathrm{~mol} / \mathrm{L} \mathrm{HNO}_{3}$, and then added to a nitrate-form AG $1 \times 8$ column (Bio-Rad Laboratories, Hercules, California), preconditioned with $70 \mathrm{ml}$ of $8 \mathrm{~mol} / \mathrm{L} \mathrm{HNO}_{3}$. After washing with six column volumes of $8 \mathrm{~mol} / \mathrm{L} \mathrm{HNO}_{3}$, Th was eluted with $90 \mathrm{ml}$ of $9 \mathrm{~mol} / \mathrm{L} \mathrm{HCl}$, evaporated down to one drop, extracted into a TTA-benzene solution, and deposited on a stainless steel disk.

Each particulate sample was transferred to a separate Teflon beaker for spiking and digestion, according to procedures given by Anderson and Fleer (1982). After digestion, the above procedures for dissolved Th were used for ${ }^{234} \mathrm{Th}$ purification.

${ }^{234} \mathrm{Th}$ activity was counted immediately on a low-level beta counter (Model BH1216) to avoid the effect of daughter ingrowth from ${ }^{228} \mathrm{Th}$. After beta counting, the samples were alpha counted again with silicon surface barrier detectors (Model Octete ${ }^{\mathrm{TM}}$ Plus, EG\&G, Gaithersburg, Maryland) to determine the yield of the ${ }^{228} \mathrm{Th}$ activity.

The detector efficiencies of the beta counter and alpha counter were cross-calibrated by using a known-activity source containing ${ }^{234} \mathrm{Th}$ and ${ }^{228} \mathrm{Th}$. Briefly, ${ }^{238} \mathrm{U}-{ }^{234} \mathrm{Th}$ equilibrium solution was mixed with ${ }^{232} \mathrm{U}_{-}{ }^{228} \mathrm{Th}$ equilibrium solution. After separation of Th from $\mathrm{U}$, the source containing Th was counted by the beta and alpha counters in sequence. The efficiency ratio of the beta detector to the alpha detector was calculated as follows:

$$
R=\frac{C_{234}}{A_{234}} / \frac{C_{228}}{A_{228}}
$$

where $\mathrm{C}_{234}$ and $\mathrm{C}_{228}$ represent the net counting rates of ${ }^{234} \mathrm{Th}$ and ${ }^{228} \mathrm{Th}$, and $\mathrm{A}_{234}$ and $\mathrm{A}_{228}$ are the added activities of ${ }^{234} \mathrm{Th}$ and ${ }^{228} \mathrm{Th}$, respectively. ${ }^{234} \mathrm{Th}$ activities of samples can be calculated as follows:

$$
A_{234 S}=C_{234 S} /(R \cdot \eta)
$$

where $A_{234 S}$ is activity of ${ }^{234} \mathrm{Th}$ in the sample, $\mathrm{C}_{234 \mathrm{~S}}$ is the net counting rate of ${ }^{234} \mathrm{Th}$ in the sample, and $\eta$ is the yield of ${ }^{234} \mathrm{Th}$, which can be obtained by ${ }^{228} \mathrm{Th}$ yield tracer. All ${ }^{234} \mathrm{Th}$ activity data were decay corrected to the midpoint of sampling, and the reported errors are propagated from the one sigma counting uncertainty. For the dissolved phase, activities of ${ }^{234} \mathrm{Th}$ were corrected for the ingrowth of ${ }^{234} \mathrm{Th}$ from ${ }^{238} \mathrm{U}$. The time elapsed from sample collection to the U-Th separation column ranged from $40 \mathrm{~h}$ to $69 \mathrm{~h}$, and the correction factors were less than $8 \% .{ }^{238} \mathrm{U}$ activities were calculated from measured salinity using the relationship, ${ }^{238} \mathrm{U}(\mathrm{dpm} / \mathrm{L})=0.07081 \bullet \mathrm{S}$, given by Chen et al. (1986).

\section{Measurements of Nutrients and Particulate Organic Carbon}

Nutrient (N, P, and Si) concentrations were measured onboard ship using standard methods and auto-analyzers. For POC analysis, $2 \mathrm{~L}$ of seawater was filtered on a precombusted $47 \mathrm{~mm} \mathrm{GF/F}$ glass fiber filter. After filtration, the filters were rinsed with $20 \mathrm{ml}$ of distilled water to remove salt and subsequently with $20 \mathrm{ml} 0.1 \mathrm{~mol} / \mathrm{L} \mathrm{HCl}$ to remove inorganic carbonate, and then stored in a freezer for POC analyses. The samples were dried at $60^{\circ} \mathrm{C}$, and POC was quantified on a Shimadzu TOC-5000A analyzer equipped with a solid sample combustion unit. The total mass of carbon per filter was corrected for the filter blank and divided by the volume filtered. Filter blanks were 4.07 $\pm 1.03 \mu \mathrm{mol} \mathrm{C}$ per $47 \mathrm{~mm} \mathrm{GF} / \mathrm{F}$ filter.

\section{Primary Productivity}

Primary productivity at station C 34 in the Canada Basin was measured by ${ }^{14} \mathrm{C}$ fixation with simulated in situ incubations. Three $100 \mathrm{ml}$ water samples per depth (two light bottles and one dark bottle) were collected from five optical depths (corresponding to 100, 50, 10, 1, and $0.1 \%$ of the surface illumination, respectively, determined with a Secchi disc) in acid-clean glass bottles. Samples were inoculated with $1.85 \times 10^{5} \mathrm{~Bq}$ of ${ }^{14} \mathrm{C}$-labeled sodium bicarbonate. The bottles were wrapped with appropriate quantities of cloth filter, which reduced the irradiance to the same level measured in the water from which the sample was taken. All of the bottles were shaken and quickly placed into a deck incubator through which running seawater flowed to maintain surface temperature. All samples were incubated for 14 hours and then filtered through a filter with a pore size of $0.45 \mu \mathrm{m}$ and a diameter of $25 \mathrm{~mm}$. The filters were fumed over concentrated $\mathrm{HCl}$ acid for $10 \mathrm{~min}$ to remove inorganic carbon. Radioactive carbon uptake was determined by a liquid scintillation spectrometer (Model 4640 Tri-Carb, Packard Instrument Company, Inc., Meriden, Connecticut). After counting, all 
calculations for primary productivity were corrected for isotope effect $(5 \%)$, dark bottle uptake, and counting efficiency. Net integrated primary productivity from the surface to the $0.1 \%$ light level $(95 \sim 98 \mathrm{~m}$ at the B50, B51, and B52 stations and $91 \mathrm{~m}$ at the $\mathrm{C} 34$ station) was calculated by trapezoidal integration of the PP depth profiles.

\section{Bacterial Production}

Bacterial production (BP) at station $\mathrm{C} 34$ was estimated by the ${ }^{3} \mathrm{H}$-thymidine (TDR) method (Parsons et al., 1984). Seawater was collected from three optical depths (corresponding to $100 \%, 50 \%$, and $1 \%$ of the surface illumination). Triplicate sets of $20 \mathrm{ml}$ seawater samples were pulsed with $3.7 \times 10^{6} \mathrm{~Bq}{ }^{3} \mathrm{H}$-thymidine (specific activity $2.22 \times 10^{12} \mathrm{~Bq} / \mathrm{mmol}$ ). To one set of samples, we added $0.1 \mathrm{ml} 40 \%$ formalin solution as a control treatment. All subsamples were incubated for $14 \mathrm{~h}$ at sea surface temperature in a flow-through, on-deck incubator. At the end of the incubation, $20 \mathrm{ml}$ of $10 \%$ trichloroacetic acid at $0^{\circ} \mathrm{C}$ was added to stop thymidine uptake and precipitate nucleotides. Each sample was filtered through a $0.22 \mu \mathrm{m}$ HA membrane filter. Both the incubation tube and the filter were rinsed three times with $5 \%$ trichloroacetic acid. Each filter was placed into a scintillation vial. Radioactivities of the samples were counted with a liquid scintillation spectrometer (Model 4640 Tri-Carb, Packard).

Bacterial production was calculated from the equation given by Parsons et al. (1984):

$\mathrm{BP}\left(\mathrm{mmol} \mathrm{TDR} \cdot \mathrm{dm}^{-3} \cdot \mathrm{h}^{-1}\right)=\mathrm{U} /(\mathrm{S} \cdot \mathrm{T} \cdot \mathrm{V}) \times 4.5 \times 10^{-13}$

where $U$ represents the radioactivity of the sample (dpm), $\mathrm{S}$ represents specific activity of ${ }^{3} \mathrm{H}-\mathrm{TDR}, \mathrm{T}$ is the incubation time, and $\mathrm{V}$ is the sample volume.

The TDR incorporation rate calculated from the above equation was multiplied by $1.4 \times 10^{18} \mathrm{cells} / \mathrm{mol}$ (Fuhrman and Azam, 1982) and $1.67 \mathrm{fmol} \mathrm{C/cell} \mathrm{(Lee} \mathrm{and} \mathrm{Fuhrman,}$ 1987 ) to yield production rates in $\mu \mathrm{mol} \mathrm{C} / \mathrm{dm}^{3} / \mathrm{h}$. Volumetric $\mathrm{BP}$ estimates were multiplied by 24 to obtain daily rates and summed over the euphotic zone by trapezoidal integration from the surface to the value at the $1 \% I_{0}$ depth.

\section{RESULTS}

\section{Hydrochemical Characteristics}

Vertical profiles of temperature, salinity, and nutrients at the four stations are shown, along with ${ }^{234} \mathrm{Th}$ data, in Figures 2 to 5 . The hydrographic properties at all sampling stations in both study areas show a similar distribution feature in the upper $25 \mathrm{~m}$ layer, with well-mixed temperature and salinity and very low nutrient concentrations. Because of the effect of sea ice, the surface salinity at station C34 was only ca. $28 \%$ (in contrast to ca. $32.5 \%$ at the Bering Sea stations). Nutrient contents in the mixed

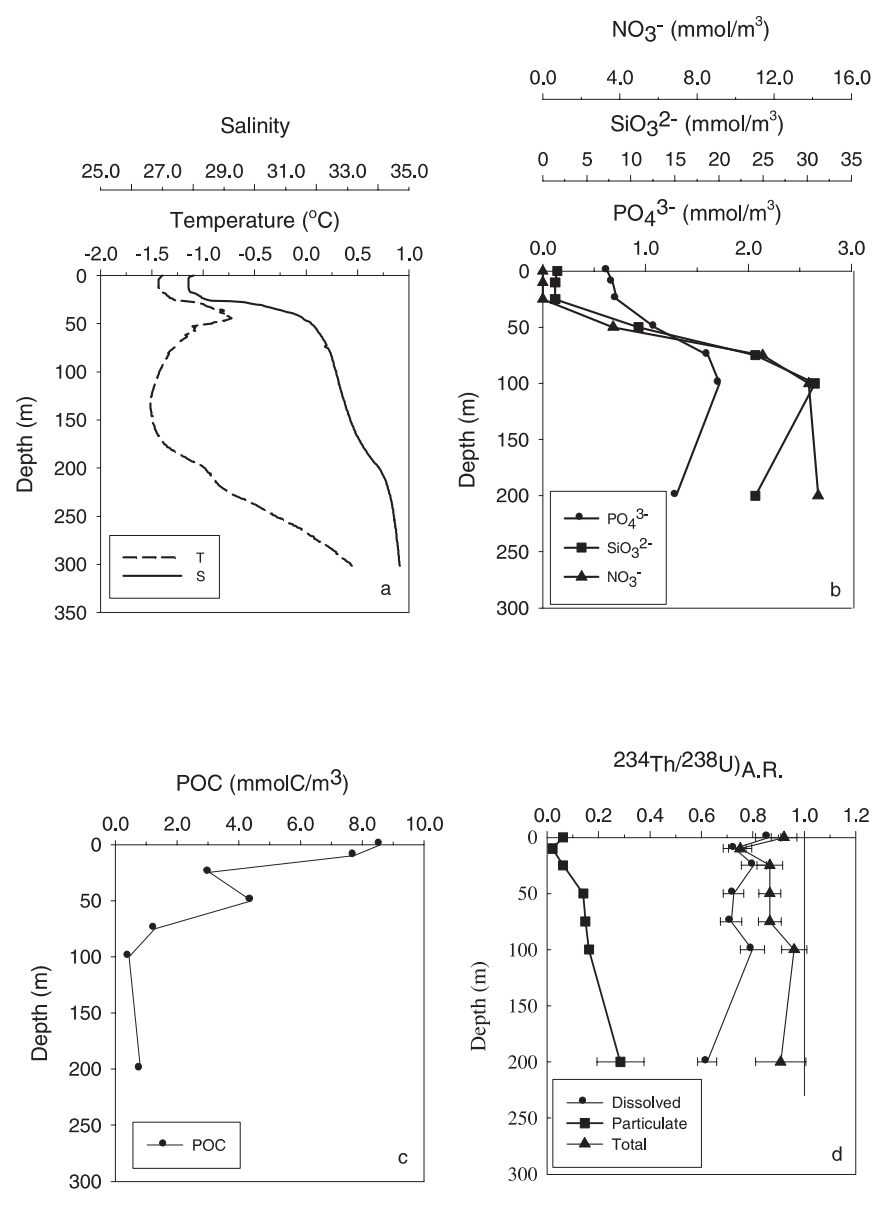

FIG. 2. Vertical profiles of temperature, salinity, nutrients, POC and ${ }^{234} \mathrm{Th} /$ $\left.{ }^{238} \mathrm{U}\right)_{\text {A.R. }}$ at station $\mathrm{C} 34$ in the Canada Basin. a) salinity and temperature, b) $\mathrm{NO}_{3}^{-}$, $\mathrm{SiO}_{3}{ }^{2-}$ and $\mathrm{PO}_{4}{ }^{3-}$, c) $\left.\mathrm{POC}, \mathrm{d}\right)$ dissolved, particulate, and total $\left.{ }^{234} \mathrm{Th} /{ }^{238} \mathrm{U}\right)_{\text {A.R. }}$.

layer were consistently low. Nitrate in the mixed layer was below the detection limit in the Canada Basin (Fig. 2b), but it was detectable at the Bering Sea stations (Figs. 3b, 4b, and $5 b)$.

Below the surface mixed layer, the hydrographic properties in the Canada Basin were distinctly different from those observed in the Bering Sea. At station C34, temperature increased from the bottom of the mixed layer to a maximum at $\sim 50 \mathrm{~m}$ and then decreased to a minimum at about $150 \mathrm{~m}$. In addition, nutrients had a maximum at a depth slightly lower than the minimum-temperature layer (Fig. 2a, b). Similar hydrochemical features in these waters were interpreted as a signature of Pacific-derived waters coming through the Bering Strait (Jones and Anderson, 1986; Cooper et al., 1997). Below $200 \mathrm{~m}$ was a warmer, more saline layer with characteristics of Atlantic waters (Fig. 2a). In the Bering Sea, the noteworthy characteristic was the presence of two halocline layers: one located between 40 and $60 \mathrm{~m}$, and the other between 160 and $220 \mathrm{~m}$. The vertical distribution of temperatures was characterized by a minimum at about $100 \mathrm{~m}$, which was sandwiched between the two haloclines (Figs. 3a, 4a, and $5 \mathrm{a})$. The mechanism of forming two halocline layers in the Bering Sea could be attributed to the seasonal variations of 

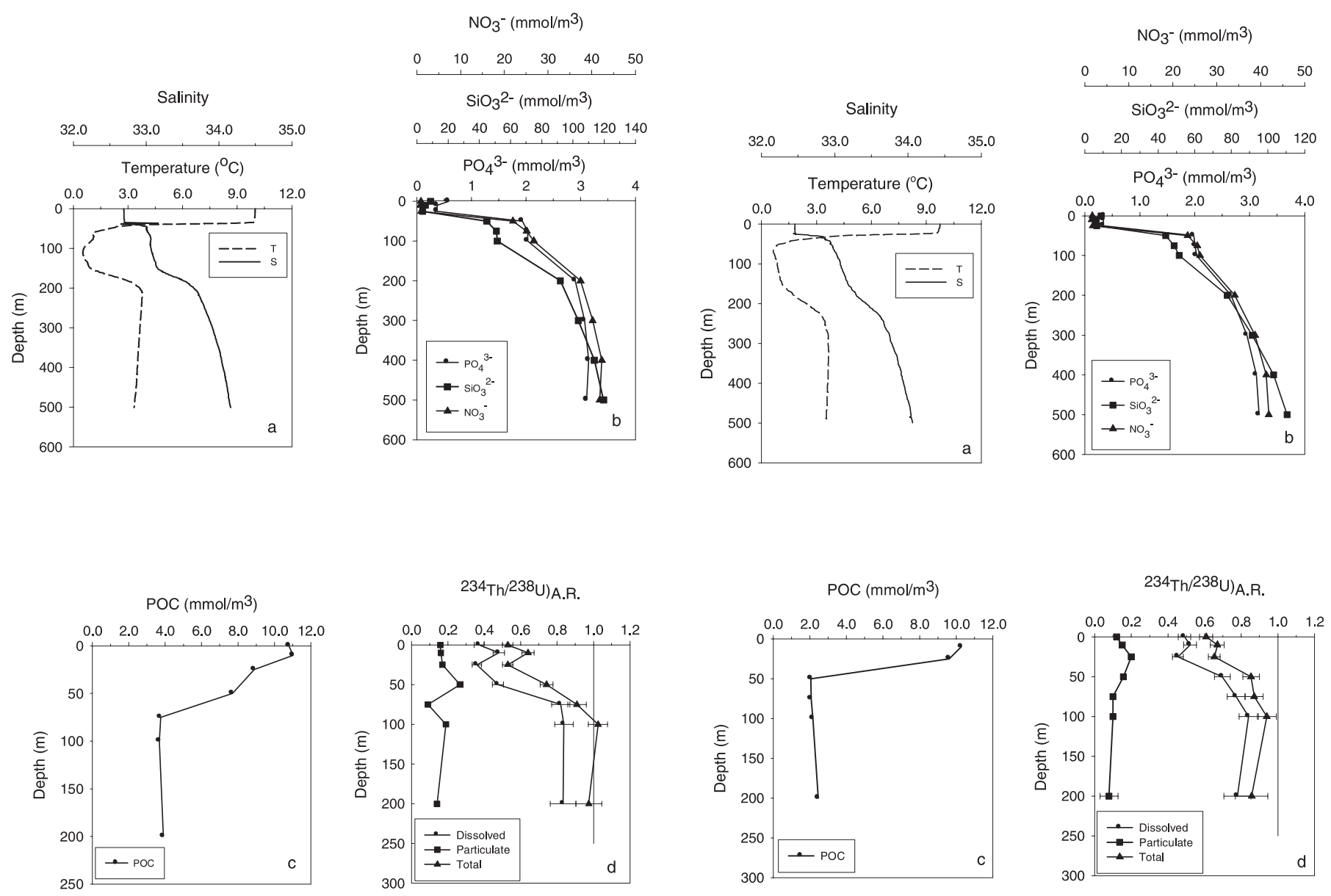

FIG. 3. Vertical profiles of temperature, salinity, nutrients, POC and ${ }^{234} \mathrm{Th} /$ ${ }^{238} \mathrm{U}_{\text {A.R. }}$ at station $\mathrm{B} 50$ in the Bering Sea. a) salinity and temperature, b) $\mathrm{NO}_{3}^{-}$, $\mathrm{SiO}_{3}{ }^{2-}$ and $\mathrm{PO}_{4}{ }^{3-}$, c) $\mathrm{POC}$, d) dissolved, particulate and total $\left.{ }^{234} \mathrm{Th} /{ }^{238} \mathrm{U}\right)_{\text {A.R. }}$.

temperature and mixing intensity in surface waters. In winter, a deep, low-temperature and well-mixed layer was formed because of the cold down to deeper depth and strong vertical mixing. Since the mixed layer was shallower in summer than in winter, and water temperature was higher in summer, a low-temperature, winter residue water was covered by warm summer waters.

\section{${ }^{234}$ Th and Particulate Organic Carbon}

${ }^{234} \mathrm{Th}$ activity concentrations are listed in Table 1 , and vertical profiles of ${ }^{234} \mathrm{Th}$ are shown in Figures $2 \mathrm{~d}, 3 \mathrm{~d}, 4 \mathrm{~d}$, and $5 \mathrm{~d}$. Dissolved ${ }^{234} \mathrm{Th}$ activity concentrations in the euphotic zone were higher in the Canada Basin than in the Bering Sea, but the opposite was true for particulate ${ }^{234} \mathrm{Th}$ activity concentrations. Dissolved and particulate ${ }^{234} \mathrm{Th}$ activity concentrations in the euphotic zone averaged 1.61 and $0.19 \mathrm{dpm} / \mathrm{L}$, respectively, in the Canada Basin, compared to 1.32 and $0.32 \mathrm{dpm} / \mathrm{L}$ in the Bering Sea. These values are consistent with those reported for the Arctic Ocean (e.g., Moran et al., 1997; Moran and Smith, 2000; Coppola et al., 2002).

FIG. 4. Vertical profiles of temperature, salinity, nutrients, POC and ${ }^{234} \mathrm{Th} /$ $\left.{ }^{238} \mathrm{U}\right)_{\text {A.R. }}$ at station B51 in the Bering Sea. a) salinity and temperature, b) $\mathrm{NO}_{3}^{-}$, $\mathrm{SiO}_{3}{ }^{2-}$ and $\mathrm{PO}_{4}{ }^{3-}$, c) $\mathrm{POC}$, d) dissolved, particulate and total $\left.{ }^{234} \mathrm{Th} /{ }^{238} \mathrm{U}\right)_{\text {A.R. }}$.

Activity concentrations of dissolved ${ }^{234} \mathrm{Th}$ were higher than those of particulate ${ }^{234} \mathrm{Th}$ in both study areas. Thus, the vertical distribution of total ${ }^{234} \mathrm{Th}$ concentrations (the sum of dissolved and particulate ${ }^{234} \mathrm{Th}$ concentrations) basically followed the pattern of dissolved ${ }^{234} \mathrm{Th}$, having a significant ${ }^{234} \mathrm{Th}$ deficit relative to its parent ${ }^{238} \mathrm{U}$ in the euphotic zone and reaching a secular equilibrium below the euphotic zone (Figs. 2d, 3d, 4d, and 5d). These ${ }^{234} \mathrm{Th}$ vertical profiles from both the Canada Basin and the Bering Sea are similar to those observed in other oceanic environments (e.g., Coale and Bruland, 1985, 1987; Murray et al., 1989; Buesseler et al., 1992, 1995).

The presence of ${ }^{234} \mathrm{Th}$ deficiency in both study areas indicates that scavenging and removal processes are also important to biogeochemical cycles in Arctic and Subarctic regions. As is evident from Table 1 and Figs. 2d, 3d, 4d, and $5 \mathrm{~d},{ }^{234} \mathrm{Th}$ partitioned primarily to the dissolved $(<0.45 \mu \mathrm{m})$ form in both study areas, with dissolved ${ }^{234} \mathrm{Th}$ forming $86 \%$ of the total Th at station C43 and $82 \%$ at Bering Sea stations. Although ${ }^{234} \mathrm{Th}$ profiles in both study areas show similar characteristics, differences in the vertical distributions of dissolved and particulate ${ }^{234} \mathrm{Th}$ are also evident. For example, total ${ }^{234} \mathrm{Th}$ deficiencies relative to ${ }^{238} \mathrm{U}$ in the 


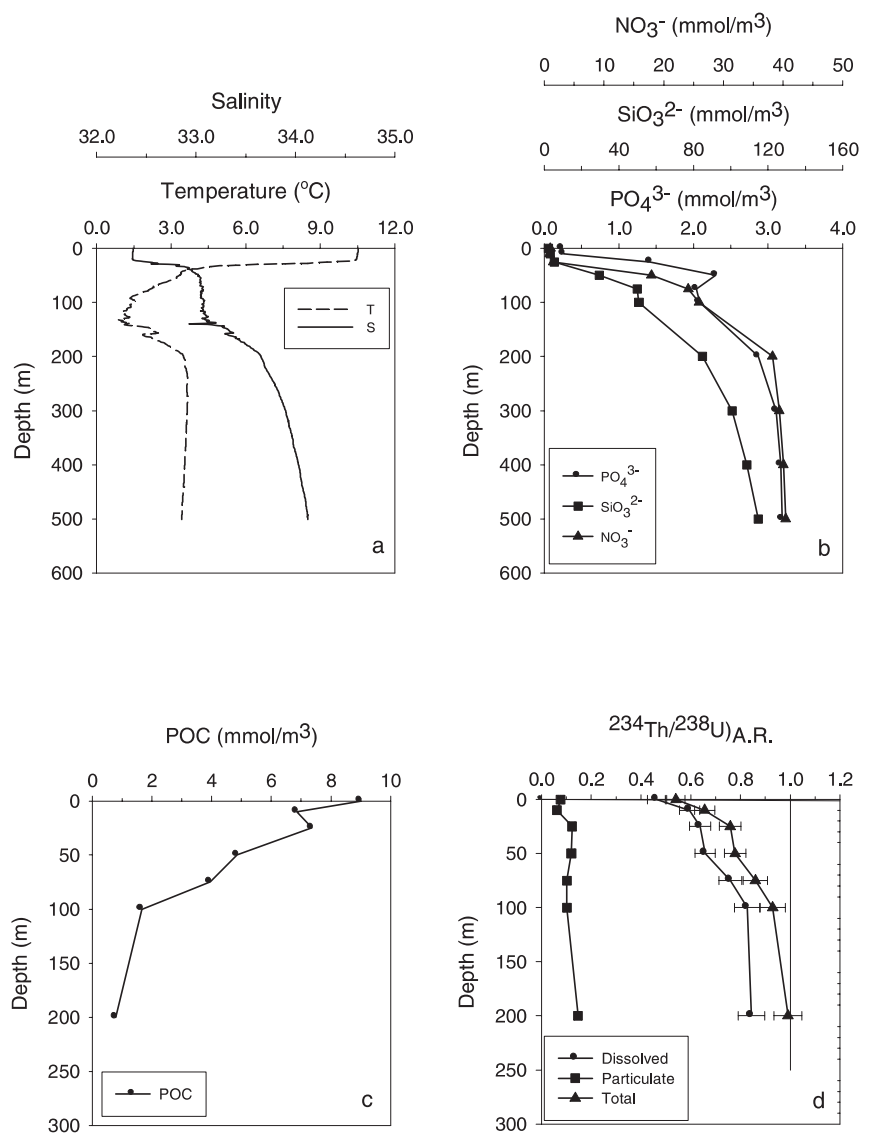

FIG. 5. Vertical profiles of temperature, salinity, nutrients, $\mathrm{POC}$ and ${ }^{234} \mathrm{Th} /$ $\left.{ }^{238} \mathrm{U}\right)_{\text {A.R. }}$ at station B52 in the Bering Sea. a) salinity and temperature, b) $\mathrm{NO}_{3}$, $\mathrm{SiO}_{3}{ }^{2-}$ and $\mathrm{PO}_{4}{ }^{3-}$, c) $\left.\mathrm{POC}, \mathrm{d}\right)$ dissolved, particulate and total $\left.{ }^{234} \mathrm{Th} /{ }^{238} \mathrm{U}\right)_{\mathrm{A} \cdot \mathrm{R} .}$.

euphotic zone were larger in the Bering Sea than in the Canada Basin (Figs. 2d, 3d, 4d, and 5d), which qualitatively suggested that scavenging and removal of ${ }^{234} \mathrm{Th}$ were more intensive in the Bering Sea than in the Canada Basin. In addition, fractions of particulate form in the total ${ }^{234} \mathrm{Th}$ in the Bering Sea (average $18 \%$ ) were slightly higher than those in the Canada Basin (average 14\%).

Interestingly, particulate ${ }^{234} \mathrm{Th}$ activities increased with increasing depth in the Canada Basin, whereas a subsurface maximum of particulate ${ }^{234} \mathrm{Th}$ activities was observed at the bottom of the mixed layer in the Bering Sea. Moran et al. (1997) and Moran and Smith (2000) also reported an increase of particulate ${ }^{234} \mathrm{Th}$ activity with increasing depth in the Beaufort Sea and the central Arctic Ocean. The increase of particulate ${ }^{234} \mathrm{Th}$ activities with increasing depth appears to be a unique characteristic in the Arctic Ocean, which has never been reported for other oceanic environments. This may be related to a continuous scavenging of ${ }^{234} \mathrm{Th}$ during the settling of the particles. When the settling rate of the particle is greater than decomposition rates due to bacterial activity, an increase of the particulate ${ }^{234} \mathrm{Th}$ with increasing depth will be observed (see Discussion).

POC concentrations decreased with depth but remained constant at over $75 \mathrm{~m}$ (Figs. 2c, 3c, 4c, and 5c), which is consistent with the results of other studies (e.g., Gordon
Primary production $\left(\mu \mathrm{mol} / \mathrm{C} / \mathrm{m}^{3} / \mathrm{h}\right)$

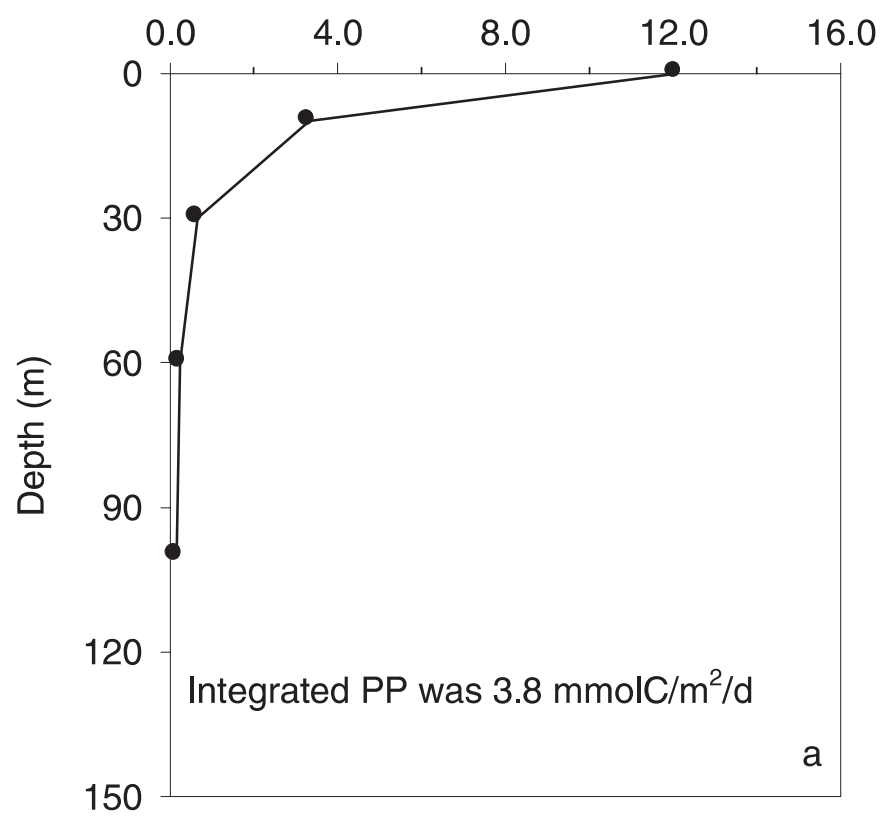

Bacterial production $\left(\mu \mathrm{molC} / \mathrm{m}^{3} / \mathrm{h}\right)$

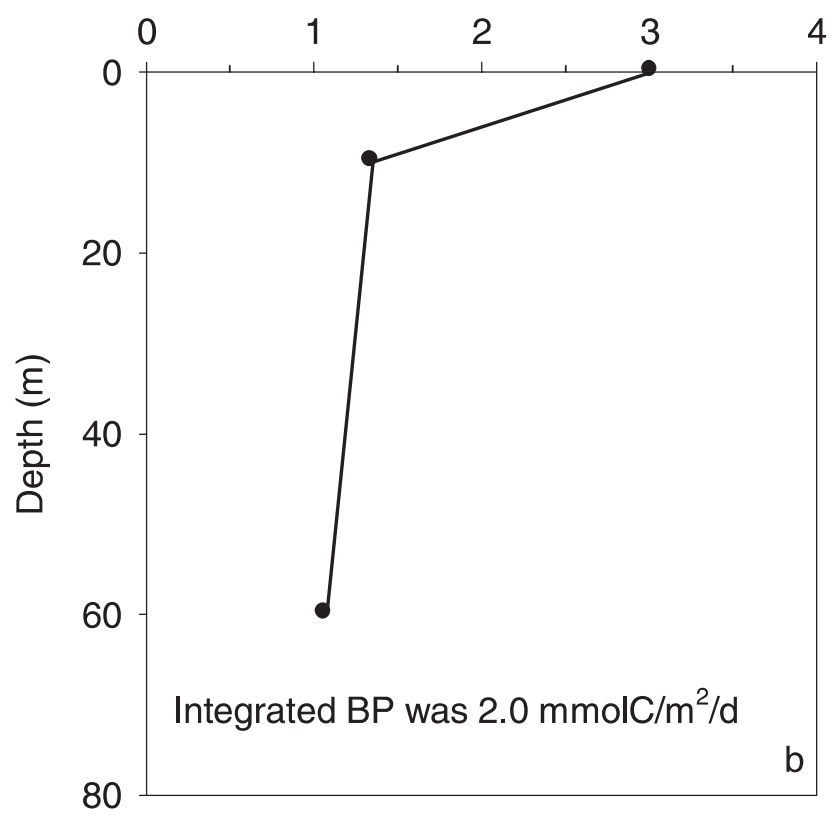

FIG. 6. Primary production and bacterial production at station C34 in the Canada Basin.

and Cranford, 1985; Moran et al., 1997). POC concentrations ranged from 0.42 to $8.67 \mathrm{mmol} \mathrm{C} / \mathrm{m}^{3}$, with an average of $3.75 \mathrm{mmol} \mathrm{C} / \mathrm{m}^{3}$ in the Canada Basin. These results are slightly higher than those reported for the central Arctic Ocean (Gordon and Cranford, 1985; Moran and Smith, 2000), but lower than those from the Barents Sea (Coppola 
TABLE $1 .{ }^{234} \mathrm{Th}$ activity concentrations and Th/U activity ratios (A.R.) in the Canada Basin and the Bering Sea.

\begin{tabular}{|c|c|c|c|c|c|c|c|c|c|}
\hline Station & Latitude \& Longitude & $\begin{array}{c}\text { Depth } \\
\text { (m) }\end{array}$ & $\begin{array}{c}{ }^{238} \mathrm{U} \\
(\mathrm{dpm} / \mathrm{L})\end{array}$ & $\begin{array}{l}\text { Diss. }{ }^{234} \mathrm{Th} \\
(\mathrm{dpm} / \mathrm{L})\end{array}$ & $\begin{array}{c}\text { Part. }{ }^{234} \mathrm{Th} \\
(\mathrm{dpm} / \mathrm{L})\end{array}$ & $\begin{array}{l}\text { Total }{ }^{234} \mathrm{Th} \\
(\mathrm{dpm} / \mathrm{L})\end{array}$ & $\mathrm{DTh} / \mathrm{U})_{\text {A.R. }}$ & $\mathrm{PTh} / \mathrm{U})_{\text {A.R. }}$ & $\mathrm{TTh} / \mathrm{U})_{\text {A.R. }}$ \\
\hline \multicolumn{10}{|c|}{ C34 (Depth: 2100 m) } \\
\hline \multirow{7}{*}{\multicolumn{2}{|c|}{$75^{\circ} 5.2^{\prime} \mathrm{N} 161^{\circ} 34.7^{\prime} \mathrm{W}$}} & 1 & 1.984 & $1.71 \pm 0.10$ & $0.12 \pm 0.02$ & $1.83 \pm 0.10$ & $0.86 \pm 0.05$ & $0.06 \pm 0.01$ & $0.92 \pm 0.05$ \\
\hline & & 10 & 1.972 & $1.44 \pm 0.09$ & $0.04 \pm 0.02$ & $1.48 \pm 0.09$ & $0.73 \pm 0.04$ & $0.02 \pm 0.01$ & $0.75 \pm 0.05$ \\
\hline & & 25 & 2.015 & $1.62 \pm 0.10$ & $0.13 \pm 0.02$ & $1.75 \pm 0.10$ & $0.80 \pm 0.05$ & $0.06 \pm 0.01$ & $0.87 \pm 0.05$ \\
\hline & & 50 & 2.254 & $1.64 \pm 0.09$ & $0.32 \pm 0.03$ & $1.95 \pm 0.10$ & $0.73 \pm 0.04$ & $0.14 \pm 0.01$ & $0.87 \pm 0.04$ \\
\hline & & 75 & 2.287 & $1.64 \pm 0.10$ & $0.34 \pm 0.03$ & $1.98 \pm 0.10$ & $0.72 \pm 0.04$ & $0.15 \pm 0.01$ & $0.87 \pm 0.04$ \\
\hline & & 100 & 2.311 & $1.85 \pm 0.11$ & $0.38 \pm 0.03$ & $2.22 \pm 0.11$ & $0.80 \pm 0.05$ & $0.16 \pm 0.01$ & $0.96 \pm 0.05$ \\
\hline & & 200 & 2.410 & $1.50 \pm 0.09$ & $0.69 \pm 0.22$ & $2.19 \pm 0.24$ & $0.62 \pm 0.04$ & $0.29 \pm 0.09$ & $0.91 \pm 0.10$ \\
\hline \multicolumn{10}{|c|}{ B50 (Depth: 1000 m) } \\
\hline \multirow{7}{*}{\multicolumn{2}{|c|}{$56^{\circ} 21.6^{\prime} \mathrm{N} 166^{\circ} 16.1^{\prime} \mathrm{E}$}} & 1 & 2.315 & $0.86 \pm 0.06$ & $0.37 \pm 0.03$ & $1.22 \pm 0.07$ & $0.37 \pm 0.03$ & $0.16 \pm 0.01$ & $0.53 \pm 0.03$ \\
\hline & & 10 & 2.315 & $1.11 \pm 0.07$ & $0.37 \pm 0.03$ & $1.48 \pm 0.08$ & $0.48 \pm 0.03$ & $0.16 \pm 0.01$ & $0.64 \pm 0.03$ \\
\hline & & 25 & 2.315 & $0.83 \pm 0.06$ & $0.39 \pm 0.03$ & $1.22 \pm 0.07$ & $0.36 \pm 0.03$ & $0.17 \pm 0.01$ & $0.53 \pm 0.03$ \\
\hline & & 50 & 2.337 & $1.11 \pm 0.07$ & $0.62 \pm 0.04$ & $1.73 \pm 0.08$ & $0.48 \pm 0.03$ & $0.27 \pm 0.02$ & $0.74 \pm 0.04$ \\
\hline & & 75 & 2.341 & $1.92 \pm 0.12$ & $0.21 \pm 0.02$ & $2.13 \pm 0.12$ & $0.82 \pm 0.05$ & $0.09 \pm 0.01$ & $0.91 \pm 0.05$ \\
\hline & & 100 & 2.341 & $1.96 \pm 0.12$ & $0.44 \pm 0.03$ & $2.40 \pm 0.12$ & $0.84 \pm 0.05$ & $0.19 \pm 0.01$ & $1.03 \pm 0.05$ \\
\hline & & 200 & 2.383 & $1.99 \pm 0.17$ & $0.34 \pm 0.03$ & $2.32 \pm 0.17$ & $0.83 \pm 0.07$ & $0.14 \pm 0.01$ & $0.97 \pm 0.07$ \\
\hline \multicolumn{10}{|c|}{ B51 (Depth: $1000 \mathrm{~m}$ ) } \\
\hline \multirow{7}{*}{\multicolumn{2}{|c|}{$56^{\circ} 0.1^{\prime} \mathrm{N} 165^{\circ} 26.7^{\prime} \mathrm{E}$}} & 1 & 2.298 & $1.13 \pm 0.08$ & $0.27 \pm 0.02$ & $1.40 \pm 0.08$ & $0.49 \pm 0.03$ & $0.12 \pm 0.01$ & $0.61 \pm 0.04$ \\
\hline & & 10 & 2.298 & $1.20 \pm 0.08$ & $0.34 \pm 0.04$ & $1.54 \pm 0.09$ & $0.52 \pm 0.04$ & $0.15 \pm 0.02$ & $0.67 \pm 0.04$ \\
\hline & & 25 & 2.299 & $1.04 \pm 0.07$ & $0.46 \pm 0.04$ & $1.50 \pm 0.08$ & $0.45 \pm 0.03$ & $0.20 \pm 0.02$ & $0.65 \pm 0.03$ \\
\hline & & 50 & 2.333 & $1.63 \pm 0.10$ & $0.37 \pm 0.03$ & $1.99 \pm 0.11$ & $0.70 \pm 0.04$ & $0.16 \pm 0.01$ & $0.85 \pm 0.05$ \\
\hline & & 75 & 2.338 & $1.81 \pm 0.11$ & $0.23 \pm 0.02$ & $2.04 \pm 0.12$ & $0.77 \pm 0.05$ & $0.10 \pm 0.01$ & $0.87 \pm 0.05$ \\
\hline & & 100 & 2.342 & $1.97 \pm 0.12$ & $0.23 \pm 0.02$ & $2.20 \pm 0.12$ & $0.84 \pm 0.05$ & $0.10 \pm 0.01$ & $0.94 \pm 0.05$ \\
\hline & & 200 & 2.367 & $1.84 \pm 0.17$ & $0.18 \pm 0.12$ & $2.03 \pm 0.21$ & $0.78 \pm 0.07$ & $0.08 \pm 0.05$ & $0.86 \pm 0.09$ \\
\hline \multicolumn{10}{|c|}{ B52 (Depth: $1000 \mathrm{~m}$ ) } \\
\hline \multirow{7}{*}{\multicolumn{2}{|c|}{$55^{\circ} 45.4^{\prime} \mathrm{N} 164^{\circ} 45.1^{\prime} \mathrm{E}$}} & 1 & 2.292 & $1.06 \pm 0.08$ & $0.18 \pm 0.02$ & $1.24 \pm 0.09$ & $0.46 \pm 0.04$ & $0.08 \pm 0.01$ & $0.54 \pm 0.04$ \\
\hline & & 10 & 2.292 & $1.36 \pm 0.09$ & $0.14 \pm 0.02$ & $1.50 \pm 0.10$ & $0.60 \pm 0.04$ & $0.06 \pm 0.01$ & $0.66 \pm 0.04$ \\
\hline & & 25 & 2.299 & $1.46 \pm 0.10$ & $0.28 \pm 0.03$ & $1.75 \pm 0.10$ & $0.64 \pm 0.04$ & $0.12 \pm 0.01$ & $0.76 \pm 0.04$ \\
\hline & & 50 & 2.338 & $1.54 \pm 0.10$ & $0.28 \pm 0.03$ & $1.82 \pm 0.10$ & $0.66 \pm 0.04$ & $0.12 \pm 0.01$ & $0.78 \pm 0.04$ \\
\hline & & 75 & 2.341 & $1.78 \pm 0.11$ & $0.24 \pm 0.03$ & $2.01 \pm 0.11$ & $0.76 \pm 0.05$ & $0.10 \pm 0.01$ & $0.86 \pm 0.05$ \\
\hline & & 100 & 2.342 & $1.94 \pm 0.12$ & $0.24 \pm 0.03$ & $2.18 \pm 0.12$ & $0.83 \pm 0.05$ & $0.10 \pm 0.01$ & $0.93 \pm 0.05$ \\
\hline & & 200 & 2.383 & $2.01 \pm 0.13$ & $0.35 \pm 0.03$ & $2.36 \pm 0.13$ & $0.84 \pm 0.05$ & $0.15 \pm 0.01$ & $0.99 \pm 0.06$ \\
\hline
\end{tabular}

et al., 2002). In addition, the POC profile at station C34 was characterized by a subsurface peak at $50 \mathrm{~m}$, which is consistent with the POC profiles reported for the Beaufort Sea (Moran and Smith, 2000). POC concentrations were higher in the Bering Sea than in the Canada Basin, with an average of $5.67 \mathrm{mmol} \mathrm{C} / \mathrm{m}^{3}$ (ranging from 0.75 to 11.08 $\left.\mathrm{mmol} \mathrm{C} / \mathrm{m}^{3}\right)$.

\section{Primary Production and Bacterial Production}

At station $\mathrm{C} 34$, both primary production and bacterial production in the euphotic zone decreased progressively with depth (Fig. 6), which is consistent with the vertical change of irradiance in the water column. Primary production in surface waters was $12.5 \mu \mathrm{mol} \mathrm{C} / \mathrm{m}^{3} / \mathrm{h}$, and close to 0 below $60 \mathrm{~m}$. Bacterial production decreased from $75 \mu \mathrm{mol} \mathrm{C} / \mathrm{m}^{3} / \mathrm{d}$ in the surface to $25 \mu \mathrm{mol} \mathrm{C} / \mathrm{m}^{3} / \mathrm{d}$ at $60 \mathrm{~m}$. The integrated primary production at this station was $3.8 \mathrm{mmol} \mathrm{C} / \mathrm{m}^{2} / \mathrm{d}$, and bacterial production was $2.0 \mathrm{mmol}$ $\mathrm{C} / \mathrm{m}^{2} / \mathrm{d}$. These values were lower than those observed during the same cruise for the Chukchi Sea shelf and Bering Sea (Chen et al., in press), but were consistent with the results obtained by Wheeler et al. (1996) and Cota et al. (1996) in the same areas.
Simultaneous measurements of primary production and bacterial production at the three stations in the Bering Sea are not available. However, we determined the surface primary production at one station very close to station B52, with a value of $0.5 \mathrm{mmol} \mathrm{C} / \mathrm{m}^{3} / \mathrm{d}$. According to the relationship between the surface primary and integrated primary production in the Bering Sea (Chen et al., in press), we estimated the integrated primary production in this region to be $19.8 \mathrm{mmol} \mathrm{C} / \mathrm{m}^{2} / \mathrm{d}$.

\section{DISCUSSION}

\section{Particle Scavenging and Removal Processes}

Th scavenging and removal rates can be calculated by using an irreversible, steady-state scavenging model (Coale and Bruland, 1987). In this model, diffusive and advective transport rates are ignored because the turnover rate of ${ }^{234} \mathrm{Th}$ in seawater is rapid as a result of its short half-life. As stated in the previous section, water masses in the Canada Basin may be transported from Pacific waters, judging from the maximum of nutrient concentrations. If Pacific waters had a long residence time in shelf regions, the ${ }^{234} \mathrm{Th}$ 
signal of Pacific or shelf waters would not be seen in the open Arctic. Previous results showed that the residence time of water masses in Arctic shelf regions was about 520 years (Rutgers van der Loeff et al., 1995; Schlosser et al., 1995), which is about 70-280 times the half-life of ${ }^{234} \mathrm{Th}$. Moran et al. (1997) suggested that shelf scavenging was of minor importance for ${ }^{234} \mathrm{Th}$ over a length scale of $\sim 100 \mathrm{~km}$, extending from the shelf into the interior basins. All of our stations are located over $150 \mathrm{~km}$ from the nearest shelf. In addition, ${ }^{234} \mathrm{Th}$ profiles showed that total ${ }^{234} \mathrm{Th}$ was in near-equilibrium with ${ }^{238} \mathrm{U}$ in the Canada Basin at depths below $100 \mathrm{~m}$, where nutrient profiles gave evidence of transport of shelf water. If advection and diffusion terms are ignored, then the mass balance for dissolved and particulate ${ }^{234} \mathrm{Th}$ can be written as:

$$
\begin{gathered}
\mathrm{dDTh} / \mathrm{dt}=\lambda_{\mathrm{Th}} \mathrm{U}-\lambda_{\mathrm{Th}} \text { DTh }-\mathrm{J}_{\mathrm{Th}} \\
\mathrm{dPTh} / \mathrm{dt}=\mathrm{J}_{\mathrm{Th}}-\lambda_{\mathrm{Th}} \text { PTh }-\mathrm{F}_{\mathrm{Th}}
\end{gathered}
$$

where U, DTh, and PTh are the activities of ${ }^{238} \mathrm{U}$, dissolved ${ }^{234} \mathrm{Th}$, and particulate ${ }^{234} \mathrm{Th}$, respectively; $\lambda_{\mathrm{Th}}$ is the decay constant of ${ }^{234} \mathrm{Th}\left(0.02876 \mathrm{~d}^{-1}\right) ; \mathrm{J}_{\mathrm{Th}}$ is the rate of removal of ${ }^{234} \mathrm{Th}$ from dissolved to particulate form; and $\mathrm{F}_{\mathrm{Th}}$ is the rate at which ${ }^{234} \mathrm{Th}$ is transported out of each water layer by particle fluxes.

The residence times of dissolved and particulate ${ }^{234} \mathrm{Th}$ can thus be calculated by assuming a steady state, i.e., $\mathrm{dDTh} / \mathrm{dt}=0$ and $\mathrm{dPTh} / \mathrm{dt}=0$ :

$$
\begin{aligned}
& \tau_{\mathrm{d}}=\mathrm{DTh} / \mathrm{J}_{\mathrm{Th}} \\
& \tau_{\mathrm{p}}=\mathrm{PTh} / \mathrm{F}_{\mathrm{Th}}
\end{aligned}
$$

Assuming that scavenging from the dissolved to the particulate form and the removal of particulate ${ }^{234} \mathrm{Th}$ follow a first-order kinetics, a scavenging rate constant $\left(\varphi_{\mathrm{d}}\right)$ and a removal rate constant $\left(\varphi_{\mathrm{p}}\right)$ can be defined as:

$$
\begin{aligned}
& \varphi_{\mathrm{d}}=1 / \tau_{\mathrm{d}} \\
& \varphi_{\mathrm{p}}=1 / \tau_{\mathrm{p}}
\end{aligned}
$$

Calculated values of $\mathrm{J}_{\mathrm{Th}}, \mathrm{F}_{\mathrm{Th}}, \tau_{\mathrm{d}}, \tau_{\mathrm{p}}, \varphi_{\mathrm{d}}$ and $\varphi_{\mathrm{p}}$ are listed in Table 2. It was evident that the rates of scavenging and removal of dissolved ${ }^{234} \mathrm{Th}\left(\mathrm{J}_{\mathrm{Th}}\right)$ and particulate ${ }^{234} \mathrm{Th}\left(\mathrm{F}_{\mathrm{Th}}\right)$ in the Canada Basin were lower than those in the Bering Sea. Correspondingly, residence times of dissolved and particulate ${ }^{234} \mathrm{Th}$ in the euphotic zone were also longer in the Canada Basin than in the Bering Sea. Considering the upper $100 \mathrm{~m}$ of the water column in the euphotic zone (0$100 \mathrm{~m}$ ), dissolved and particulate ${ }^{234} \mathrm{Th}$ removal fluxes in the Canada Basin were $1539 \mathrm{dpm} / \mathrm{m}^{2} / \mathrm{d}$ and $824 \mathrm{dpm} / \mathrm{m}^{2} / \mathrm{d}$, respectively, whereas they ranged from 2118 to $2312 \mathrm{dpm} /$ $\mathrm{m}^{2} / \mathrm{d}$ and from 1373 to $1648 \mathrm{dpm} / \mathrm{m}^{2} / \mathrm{d}$, respectively, in the Bering Sea. Dissolved and particulate ${ }^{234}$ Th fluxes in the Canada Basin are similar to values obtained from the
Bermuda Atlantic Time Series (BATS) Site (0-150 m; Buesseler, 1998); the NE Polynya, Greenland (0-50 m; Cochran et al., 1995); and the central Arctic Ocean (0-30 m; Moran et al, 1997). However, they are lower than the values obtained from NABE $(0-75 \mathrm{~m}$; Buesseler et al., 1992), EqPac (0-100 m; Buesseler et al., 1995; Bacon et al., 1996; Murray et al., 1996), the Arabian Sea (0-100 m; Buesseler et al., 1998), the Beaufort Sea (0-200 m; Moran and Smith, 2000), and the Weddell Sea (0-100 m; Rutgers van der Loeff et al., 1997). In contrast, dissolved and particulate ${ }^{234} \mathrm{Th}$ fluxes in the Bering Sea are consistent with most values from the open ocean. These results suggested that scavenging and removal processes in the Canada Basin were less intensive than in the Bering Sea and other open ocean regions.

\section{POC Export Fluxes}

On the basis of the scavenging model described above, the export fluxes of POC can be calculated using the total ${ }^{234} \mathrm{Th}$ deficit between 0 and $100 \mathrm{~m}$ and the POC/PTh ratio at the depth of $100 \mathrm{~m}$ (Buesseler et al., 1992):

$$
\left.\mathrm{F}_{\mathrm{POC}}=\frac{\mathrm{POC}}{\mathrm{PTh}}\right)_{100 \mathrm{~m}} \times \lambda_{\mathrm{Th}} \int_{0 \mathrm{~m}}^{100 \mathrm{~m}} \mathrm{~F}_{\mathrm{Th}}
$$

The reliability of this approach mainly depends on two parameters, the $\mathrm{POC} /{ }^{234} \mathrm{Th}$ ratio and particulate ${ }^{234} \mathrm{Th}$ export flux. In the present study, we used the $\mathrm{POC} /{ }^{234} \mathrm{Th}$ ratios in suspended particles, rather than those on sinking particles. Numerous studies suggested that the POC/PTh ratio of particulate matter decreases with increasing particle size (e.g., Moran and Buesseler, 1993; Buesseler et al., 1995; Guo et al., 2002). Thus, our POC export fluxes could be upper estimates. However, two recent papers pointed out that the POC/PTh ratios increased with increasing particle size in regions dominated by large diatoms (Buesseler et al., 1998; Charette and Moran, 1999); therefore, POC export fluxes based on suspended particles could be lower estimates.

Our observed POC/PTh ratios decreased significantly with increasing water depth (Fig. 7), and similar results have been reported for other oceans (e.g., Bacon et al., 1996; Murray et al., 1996; Santschi et al., 1999). The changes of POC/PTh ratios could indicate that organic carbon is preferentially remineralized relative to ${ }^{234} \mathrm{Th}$. It is interesting to note that POC decreased with increasing depth, while particulate ${ }^{234} \mathrm{Th}$ concentration slightly increased with increasing depth. It is likely that ${ }^{234} \mathrm{Th}$ resided on particles during the remineralization of $\mathrm{POC}$, resulting in a larger gradient in the $\mathrm{POC} /{ }^{234} \mathrm{Th}$ ratio. If the $\mathrm{POC} / \mathrm{PTh}$ ratio is taken from the integrated value in the euphotic zone (Cochran et al., 1995; Moran et al., 1997; Moran and Smith, 2000), the POC export flux would have been overestimated. Therefore, the POC/PTh ratio at the bottom layer of the euphotic zone was used here to estimate the POC export fluxes. The POC/PTh ratio in the Canada Basin was $1.2 \mu \mathrm{mol} / \mathrm{dpm}$, which is significantly lower than 
40 M. CHEN et al.

TABLE 2. Estimated ${ }^{234}$ Th deficiencies, fluxes and residence times.

\begin{tabular}{|c|c|c|c|c|c|c|c|}
\hline Station & Sampling depth (m) & $\mathrm{J}_{\mathrm{Th}}\left(\mathrm{dpm} / \mathrm{m}^{3} / \mathrm{d}\right)$ & $\mathrm{F}_{\mathrm{Th}}\left(\mathrm{dpm} / \mathrm{m}^{3} / \mathrm{d}\right)$ & $\tau_{\mathrm{d}} *(\mathrm{~d})$ & $\tau_{\mathrm{p}}^{*}(\mathrm{~d})$ & $\varphi_{\mathrm{d}}\left(\mathrm{d}^{-1}\right)$ & $\varphi_{\mathrm{p}}\left(\mathrm{d}^{-1}\right)$ \\
\hline \multirow[t]{7}{*}{$\mathrm{C} 34$} & 0 & $8.0 \pm 2.8$ & $4.5 \pm 2.9$ & $213 \pm 76$ & $27 \pm 18$ & $0.005 \pm 0.002$ & $0.037 \pm 0.024$ \\
\hline & 10 & $15.4 \pm 2.5$ & $14.2 \pm 2.6$ & $94 \pm 16$ & $3 \pm 2$ & $0.011 \pm 0.002$ & $0.333 \pm 0.166$ \\
\hline & 25 & $11.4 \pm 2.8$ & $7.8 \pm 2.9$ & $142 \pm 36$ & $16 \pm 6$ & $0.007 \pm 0.002$ & $0.061 \pm 0.024$ \\
\hline & 50 & $17.8 \pm 2.6$ & $8.7 \pm 2.7$ & $92 \pm 14$ & $37 \pm 12$ & $0.011 \pm 0.002$ & $0.027 \pm 0.009$ \\
\hline & 75 & $18.7 \pm 2.8$ & $8.8 \pm 2.9$ & $88 \pm 14$ & $39 \pm 13$ & $0.011 \pm 0.002$ & $0.026 \pm 0.009$ \\
\hline & 100 & $13.4 \pm 3.1$ & $2.6 \pm 3.2$ & $138 \pm 33$ & $147 \pm 186$ & $0.007 \pm 0.002$ & $0.007 \pm 0.009$ \\
\hline & 200 & $26.1 \pm 2.5$ & $6.4 \pm 6.8$ & $58 \pm 7$ & $108 \pm 121$ & $0.017 \pm 0.002$ & $0.009 \pm 0.012$ \\
\hline \multirow[t]{7}{*}{ B50 } & 0 & $41.9 \pm 1.8$ & $31.4 \pm 2.0$ & $21 \pm 2$ & $12 \pm 1$ & $0.049 \pm 0.004$ & $0.085 \pm 0.008$ \\
\hline & 10 & $34.7 \pm 2.1$ & $23.9 \pm 2.3$ & $32 \pm 3$ & $16 \pm 2$ & $0.031 \pm 0.003$ & $0.064 \pm 0.008$ \\
\hline & 25 & $42.7 \pm 1.8$ & $31.4 \pm 1.9$ & $20 \pm 2$ & $13 \pm 1$ & $0.051 \pm 0.004$ & $0.079 \pm 0.008$ \\
\hline & 50 & $35.3 \pm 2.0$ & $17.4 \pm 2.3$ & $31 \pm 3$ & $36 \pm 5$ & $0.032 \pm 0.003$ & $0.028 \pm 0.004$ \\
\hline & 75 & $12.2 \pm 3.4$ & $6.1 \pm 3.4$ & $157 \pm 44$ & $35 \pm 20$ & $0.006 \pm 0.002$ & $0.029 \pm 0.017$ \\
\hline & 100 & $11.0 \pm 3.5$ & $-1.7 \pm 3.6$ & $178 \pm 57$ & $-257 \pm 534$ & $0.006 \pm 0.002$ & $-0.004 \pm 0.027$ \\
\hline & 200 & $11.4 \pm 4.8$ & $1.8 \pm 4.9$ & $174 \pm 74$ & $186 \pm 504$ & $0.006 \pm 0.003$ & $0.005 \pm 0.014$ \\
\hline \multirow[t]{7}{*}{ B51 } & 0 & $33.7 \pm 2.2$ & $25.8 \pm 2.4$ & $33 \pm 3$ & $11 \pm 1$ & $0.030 \pm 0.003$ & $0.094 \pm 0.012$ \\
\hline & 10 & $31.7 \pm 2.3$ & $21.8 \pm 2.5$ & $38 \pm 4$ & $16 \pm 2$ & $0.027 \pm 0.003$ & $0.063 \pm 0.010$ \\
\hline & 25 & $36.1 \pm 2.0$ & $22.9 \pm 2.2$ & $29 \pm 2$ & $20 \pm 3$ & $0.035 \pm 0.003$ & $0.050 \pm 0.006$ \\
\hline & 50 & $20.3 \pm 2.9$ & $9.8 \pm 3.0$ & $80 \pm 12$ & $37 \pm 12$ & $0.013 \pm 0.002$ & $0.027 \pm 0.009$ \\
\hline & 75 & $15.3 \pm 3.3$ & $8.7 \pm 3.3$ & $118 \pm 26$ & $27 \pm 10$ & $0.008 \pm 0.002$ & $0.038 \pm 0.015$ \\
\hline & 100 & $10.7 \pm 3.5$ & $4.1 \pm 3.6$ & $184 \pm 61$ & $57 \pm 50$ & $0.005 \pm 0.002$ & $0.018 \pm 0.016$ \\
\hline & 200 & $15.0 \pm 5.0$ & $9.8 \pm 6.0$ & $123 \pm 42$ & $19 \pm 17$ & $0.008 \pm 0.003$ & $0.053 \pm 0.047$ \\
\hline \multirow[t]{7}{*}{ B52 } & 0 & $35.4 \pm 2.4$ & $30.3 \pm 2.5$ & $30 \pm 3$ & $6 \pm 1$ & $0.033 \pm 0.003$ & $0.172 \pm 0.027$ \\
\hline & 10 & $26.7 \pm 2.7$ & $22.7 \pm 2.7$ & $51 \pm 6$ & $6 \pm 1$ & $0.020 \pm 0.002$ & $0.161 \pm 0.031$ \\
\hline & 25 & $24.0 \pm 2.8$ & $15.9 \pm 2.9$ & $61 \pm 8$ & $18 \pm 4$ & $0.016 \pm 0.002$ & $0.056 \pm 0.011$ \\
\hline & 50 & $23.0 \pm 2.8$ & $14.9 \pm 2.9$ & $67 \pm 9$ & $19 \pm 4$ & $0.015 \pm 0.002$ & $0.053 \pm 0.012$ \\
\hline & 75 & $16.3 \pm 3.1$ & $9.4 \pm 3.2$ & $109 \pm 22$ & $25 \pm 9$ & $0.009 \pm 0.002$ & $0.040 \pm 0.014$ \\
\hline & 100 & $11.6 \pm 3.4$ & $4.8 \pm 3.5$ & $167 \pm 50$ & $50 \pm 38$ & $0.006 \pm 0.002$ & $0.020 \pm 0.015$ \\
\hline & 200 & $10.7 \pm 3.7$ & $0.6 \pm 3.8$ & $189 \pm 67$ & $583 \pm 724$ & $0.005 \pm 0.002$ & $0.002 \pm 0.013$ \\
\hline
\end{tabular}

* The errors associated with the residence times were calculated through the propagation of counting errors.

previously estimated values for the Arctic Ocean (e.g., Cochran et al., 1995; Moran et al., 1997; Moran and Smith, 2000; Coppola et al., 2002). POC/PTh ratios at the bottom of the euphotic zone in the Bering Sea ranged from 7.0 to $9.4 \mu \mathrm{mol} / \mathrm{dpm}$, with an average of $8 \mu \mathrm{mol} / \mathrm{dpm}$, a value similar to those in many previous studies, such as NABE (Buesseler et al., 1992), BATS (Buesseler, 1998), and studies in the Weddell Sea (Rutgers van der Loeff et al., 1997), the central Arctic Ocean (Moran et al., 1997) and the Beaufort Sea (Moran and Smith, 2000).

The other limitation on the calculation of the POC export flux is the use of steady-state particulate ${ }^{234} \mathrm{Th}$ fluxes. Buesseler et al. (1995) suggested that a steady-state model could underestimate the particulate ${ }^{234} \mathrm{Th}$ flux when removal of ${ }^{234} \mathrm{Th}$ progressively increases with time at a site (e.g., during a bloom event). Our data are insufficient to evaluate the steady-state assumption. However, as pointed out by Cochran et al. (1995), the net effects of the steadystate assumption and the presumed higher $\mathrm{POC} / \mathrm{PTh}$ ratio of suspended particles on the calculation of POC export flux could offset each other.

Values of POC fluxes calculated from ${ }^{234} \mathrm{Th}$ deficiencies are listed in Table 3 and Figure 8. Export fluxes of $\mathrm{POC}$ in the Bering Sea were higher than those in the Canada Basin, ranging from 10 to $15 \mathrm{mmol} \mathrm{C} / \mathrm{m}^{2} / \mathrm{d}$. A flux of $1 \mathrm{mmol} \mathrm{C} / \mathrm{m}^{2} / \mathrm{d}$ in the Canada Basin is similar to the values in the central Arctic Ocean (Moran et al., 1997) and

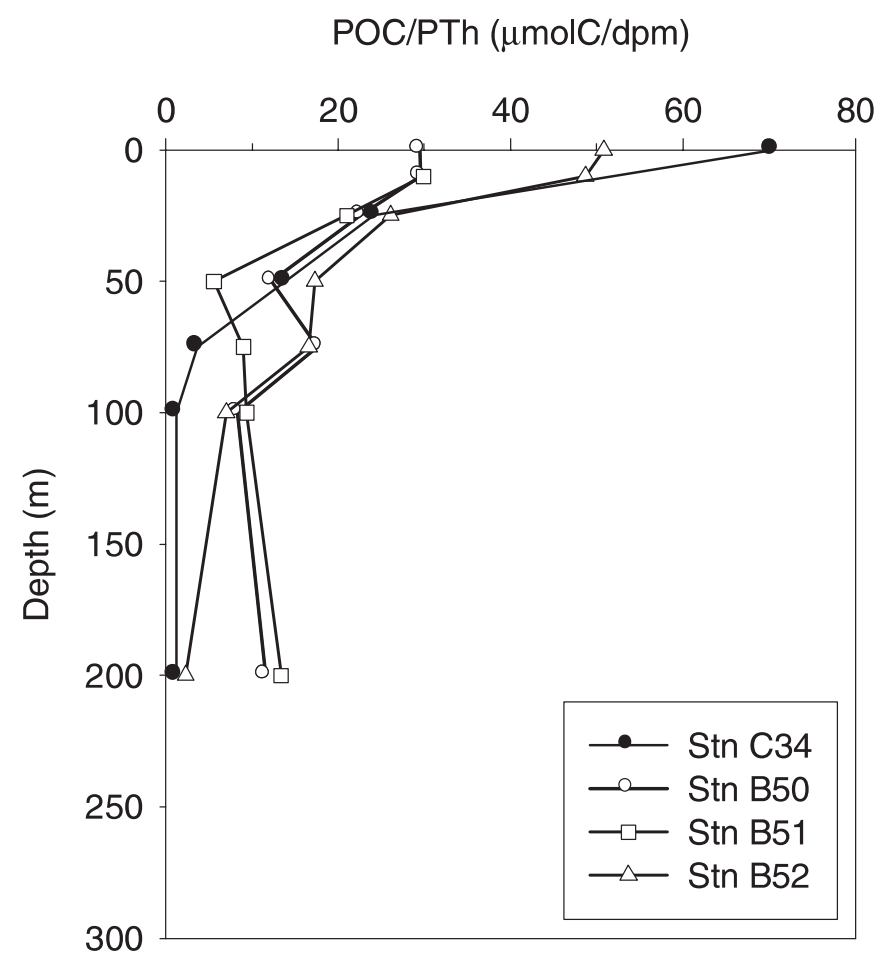

FIG. 7. Vertical profiles of POC/PTh ratios in the Canada Basin and the Bering Sea. 
TABLE 3. POC/PTh ratios and POC export fluxes.

\begin{tabular}{|c|c|c|c|c|c|c|}
\hline Station & $\begin{array}{l}\text { Sampling depth } \\
\text { (m) }\end{array}$ & $\begin{array}{c}\mathrm{POC} / \mathrm{PTh} \\
(\mu \mathrm{mol} / \mathrm{dpm})\end{array}$ & $\begin{array}{l}\text { Export layer } \\
(\mathrm{m})\end{array}$ & $\underset{\left(\mathrm{dpm} / \mathrm{m}^{2} / \mathrm{d}\right)}{\sum \mathrm{F}_{\mathrm{t}}}$ & $\underset{\left(\mathrm{mmol} \mathrm{C} / \mathrm{m}^{2}\right)}{\sum \mathrm{POC}}$ & $\begin{array}{c}\text { POC flux } \\
\left(\mathrm{mmol} \mathrm{C} / \mathrm{m}^{2} / \mathrm{d}\right)\end{array}$ \\
\hline C34 & $\begin{array}{l}0 \\
10 \\
25 \\
50 \\
75 \\
100 \\
200\end{array}$ & $\begin{array}{c}70.4 \pm 11.5 \\
\text { n.d. } \\
24.2 \pm 3.6 \\
13.9 \pm 1.2 \\
3.7 \pm 0.3 \\
1.2 \pm 0.1 \\
1.2 \pm 0.4\end{array}$ & $0-100$ & $\begin{array}{l}257 \pm 35 \\
824 \pm 95\end{array}$ & 163 & $6.2 \pm 1.2$ \\
\hline B50 & $\begin{array}{l}0 \\
10 \\
25 \\
50 \\
75 \\
100 \\
200\end{array}$ & $\begin{aligned} 29.5 & \pm 2.1 \\
29.6 & \pm 2.2 \\
22.6 & \pm 1.6 \\
12.3 & \pm 0.8 \\
17.6 & \pm 1.8 \\
8.3 & \pm 0.6 \\
11.6 & \pm 1.0\end{aligned}$ & $\begin{array}{l}0-25 \\
0-100\end{array}$ & $\begin{array}{c}691 \pm 27 \\
1648 \pm 93\end{array}$ & 259 & $\begin{array}{l}15.6 \pm 1.3 \\
13.7 \pm 1.3\end{array}$ \\
\hline B52 & $\begin{array}{l}0 \\
10 \\
25 \\
50 \\
75 \\
100 \\
200\end{array}$ & $\begin{aligned} 50.8 & \pm 6.9 \\
48.7 & \pm 7.2 \\
26.1 & \pm 2.3 \\
17.3 & \pm 1.7 \\
16.6 & \pm 1.8 \\
7.0 & \pm 0.8 \\
2.3 & \pm 0.2\end{aligned}$ & $0-100$ & $\begin{array}{c}554 \pm 35 \\
1420 \pm 118\end{array}$ & 186 & $9.9 \pm 1.4$ \\
\hline
\end{tabular}

${ }^{1}$ n.d $=$ not determined.

the Beaufort Sea (Moran and Smith, 2000). Notice that the difference of POC export fluxes between the Bering Sea and the Canada Basin resulted largely from the difference in POC/PTh ratios and particulate ${ }^{234} \mathrm{Th}$ fluxes between these two study areas (Fig. 8). Particulate ${ }^{234}$ Th flux was about 1.8 times lower in the Canada Basin than in the Bering Sea, while the POC/PTh ratio was 6.9 times lower. We argue that the variation gradient in POC export in the study areas was driven by the POC/PTh ratio and the particulate ${ }^{234} \mathrm{Th}$ flux, although the effect of $\mathrm{POC} /{ }^{234} \mathrm{Th}$ ratios was more important. By comparison, Charette et al. (1999) found that the POC export gradient was driven by the $\mathrm{POC} /{ }^{234} \mathrm{Th}$ ratio rather than by the particulate ${ }^{234} \mathrm{Th}$ flux in the subarctic northeast Pacific Ocean.

\section{Carbon Cycle in the Upper Ocean}

Buesseler (1998) defined the ThE ratio as the ratio of ${ }^{234} \mathrm{Th}$-derived POC export to primary production. Similarly, the ratio of bacterial production to primary production is called the B-ratio, which represents the fraction of carbon uptake that is remineralized via microbial processes. From the POC export at the base of the euphotic zone, ThE ratios were calculated to be $26 \%$ at the Canada Basin station and about $70 \%$ at Bering Sea stations. These values were higher than those in mid- and low-latitude sea areas (Buesseler et al., 1995, 1998; Bacon et al., 1996; Murray et al., 1996; Buesseler, 1998; Benitez-Nelson et al., 2001). Relatively high ThE ratios were also found in other high-latitude sites, such as the NE Polynya off Greenland (> 50\%; Cochran et al., 1995), the Southern Polar Front (> 25\%; Rutgers van der Loeff et al., 1997), the Bellingshausen Sea (40\%; Shimmield and Ritchie, 1995) and the central Arctic Ocean ( 20 to several hundred percent; Moran et al., 1997). The decoupling of production and particulate export in the upper ocean in high-latitude areas was attributed to the presence of large phytoplankton, diatoms in particular (Buesseler, 1998 and references therein). One might expect that high-latitude areas have a very high ThE ratio. Our estimated ThE ratio and the highly variable ThE ratios reported by Moran et al. (1997) suggest that temporal and spatial variation of planktonic species may regulate the ThE ratio in the Arctic. The delay in POC export relative to the temporal peak in primary production may result in ThE ratios greater than $100 \%$. In addition, ice algae production and POC from ice rafting may contribute to the higher ThE ratios reported.

The B-ratio at the Canada Basin station was 52\%. This value was consistent with those measured for the central Arctic Ocean (e.g., Wheeler et al., 1996; Rich et al., 1997) and the Weddell Sea (e.g., Cota et al., 1990), but higher than those reported for other areas. For example, bacterial 

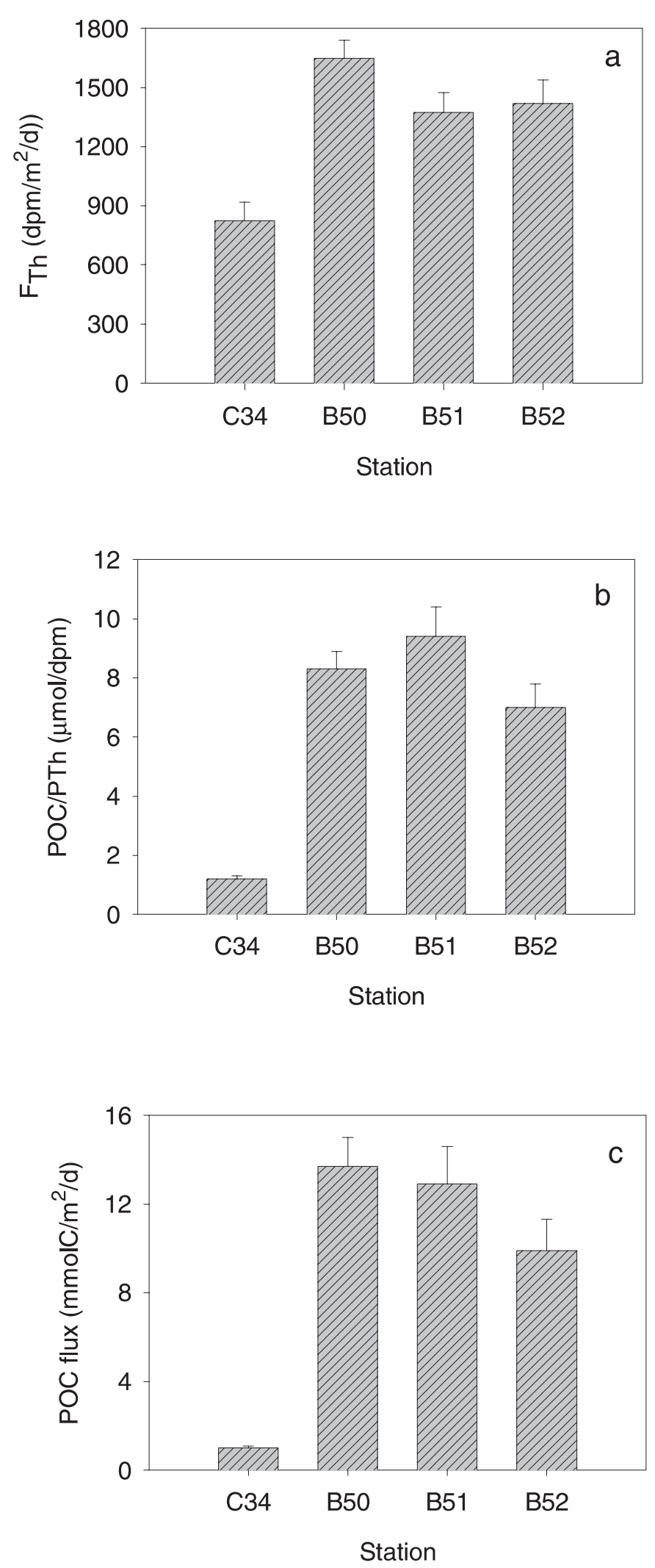

FIG. $8 .{ }^{234}$ Th fluxes, POC/PTh ratios and POC fluxes in the Canada Basin and the Bering Sea. production was about $10 \%$ of the primary production in the Subarctic North Pacific (Kirchman et al., 1993) and Antarctic South Atlantic (Kuparinen and Bjornsen, 1992), $15 \%$ in the equatorial Pacific (Kirchman et al., 1995), and $10-15 \%$ in the Sargasso Sea (Carlson et al., 1996). The relatively high B-ratio indicates that bacterial activity is not depressed in the cold Arctic waters; instead, heterotrophic microbial activity plays an important role in Arctic carbon cycling.

Overall, given measurements of primary production, bacterial production, and POC export flux, the carbon flow path in the study areas could be depicted as follows. Of the carbon uptake by phytoplankton in the Canada Basin, 26\% of the organic carbon was exported from the euphotic zone, and $52 \%$ was remineralized by microbial processes. The other $22 \%$ of organic carbon would be transported into the higher trophic levels. The scenario of carbon cycling in the Bering Sea is different from that in the Canada Basin. Most of the organic carbon synthesized by phytoplankton was exported from the euphotic zone (about $70 \%$ ). If we assume that the B-ratio in this region is 10\% (Kirchman et al., 1993), about $20 \%$ of organic carbon would be transported into the higher trophic levels, a fraction similar to that of the Canada Basin.

\section{ACKNOWLEDGEMENTS}

Without the assistance of the officers and crew of the R/V Xue Long, this work would not have been possible. We wish to thank Mingming Jin and Yong Lu for nutrient measurements, Guoping Gao, Yutian Jiao and Jinping Zhao for providing the CTD data, and three anonymous reviewers for constructive comments. This work was supported by the Chinese First Arctic Expedition Foundation and the Chinese National Science Foundation (Grant: 40076024).

\section{REFERENCES}

ANDERSON, R.F., and FLEER, A.P. 1982. Determination of natural actinides and plutonium in marine particle material. Analytical Chemistry 54:1142-1147.

BACON, M.P., HUH, C.A., and MOORE, R.M. 1989. Vertical profiles of some natural radionuclides over the Alpha Ridge, Arctic Ocean. Earth and Planetary Science Letters 95:15-22.

BACON, M.P., COCHRAN, J.K., HIRSCHBERG, D., HAMMAR, T.R., and FLEER, A.P. 1996. Export flux of carbon at the Equator during the EqPac time-series cruises estimated from ${ }^{234}$ Th measurements. Deep-Sea Research II 43:1133-1154.

BENITEZ-NELSON, C.R., BUESSELER, K.O., KARL, D.M., and ANDREWS, J. 2001. A time-series study of particulate matter export in the North Pacific Subtropical Gyre based on ${ }^{234} \mathrm{Th}:{ }^{238} \mathrm{U}$ disequilibrium. Deep-Sea Research 48:2595-2611.

BUESSELER, K.O. 1998. The decoupling of production and particulate export in the surface ocean. Global Biogeochemical Cycles 12(2):297-310. 
BUESSELER, K.O., BACON, M.P., COCHRAN, J.K., and LIVINGSTON, H.D. 1992. Carbon and nitrogen export during the JGOFS North Atlantic Bloom Experiment estimated from ${ }^{234} \mathrm{Th}:{ }^{238} \mathrm{U}$ disequilibria. Deep-Sea Research 39:1115-1137.

BUESSELER, K.O., ANDREWS, J.A., HARTMAN, M.C., BELASTOCK, R., and CHAI, F. 1995. Regional estimates of the export flux of particulate organic carbon derived from thorium-234 during the JGOFS EQPAC program. Deep-Sea Research II 42:777-804.

BUESSELER, K.O., BALL, L., ANDREWS, J.E., BENITEZNELSON, C.R., BELASTOCK, R., CHAI, F., and CHAO, Y. 1998. Upper ocean export of particulate organic carbon in the Arabian Sea derived from thorium-234. Deep-Sea Research II 45:2461-2488.

BUESSELER, K.O., BALL, L., ANDREWS, J., COCHRAN, J.K., HIRSCHBERG, D.J., BACON, M.P., FLEER, A., and BRZEZINSKI, M. 2001. Upper ocean export of particulate organic carbon and biogenic silica in the Southern Ocean along $170^{\circ}$ W. Deep-Sea Research II 48(19/20):4275-4297.

CAI, P.-H., HUANG, Y.P., CHEN, M., GUO, L., LIU, G.-S., and QIU, Y.-S. 2002. New production based on ${ }^{228} \mathrm{Ra}$-derived nutrient budgets and thorium-estimated POC export at an intercalibration station in the South China Sea. Deep-Sea Research 49(1): 91- 104 .

CARLSON, C.A., DUCKLOW, H.W., and SLEETER, T.D. 1996. Stocks and dynamics of bacterioplankton in the northwestern Sargasso Sea. Deep-Sea Research II 43:491-516.

CHARETTE, M.A., and MORAN, S.B. 1999. Rates of particle scavenging and particulate organic carbon export estimated using ${ }^{234} \mathrm{Th}$ as a tracer in the subtropical and equatorial Atlantic Ocean. Deep-Sea Research 46:885-906.

CHARETTE, M.A., MORAN, S.B., and BISHOP, J.K. 1999. ${ }^{234}$ Th as a tracer of particulate organic carbon export in the Subarctic Pacific Ocean. Deep-Sea Research II 46:2833-2861.

CHEN, J.H., EDWARDS, R.L., and WASSERBURG, G.J. 1986. ${ }^{238} \mathrm{U},{ }^{234} \mathrm{U}$ and ${ }^{232} \mathrm{Th}$ in seawater. Earth and Planetary Science Letters 80:241-251.

CHEN, M., HUANG, Y.P., and QIU, Y.S. 1997. Enrichment, purification and determination of ${ }^{238} \mathrm{U}$ and ${ }^{234} \mathrm{Th}$ in natural seawater. Journal of Isotopes 10(4):199-204.

CHEN, M., HUANG, Y.P., CAI, P.H., and QIU, Y.S. In press. Primary production, bacterial production and particulate organic carbon export fluxes in the Arctic Ocean and Bering Sea: Application of isotopic tracers. Progress in Chinese First Arctic Expedition. Beijing: China Ocean Press (2003).

COALE, K.H., and BRULAND, K.W. $1985 .{ }^{234} \mathrm{Th}:{ }^{238} \mathrm{U}$ disequilibria within the California current. Limnology and Oceanography $30: 22-33$.

_-1987. Oceanic stratified euphotic zone as elucidated by ${ }^{234} \mathrm{Th}:{ }^{238} \mathrm{U}$ disequilibria. Limnology and Oceanography 32(1):189-200.

COCHRAN, J.K., BARNES, C., ACHMAN, D., and HIRSCHBERG, D.T. 1995. Thorium-234/Uranium-238 disequilibrium as an indicator of scavenging rates and particulate organic carbon fluxes in the Northeast Water Polynya, Greenland. Journal of Geophysical Research 100(C3):4399-4410.
CODISPOTI, L.A., FRIEDERICH, G.E., SAKAMOTO, C.M., and GORDON, L.I. 1991. Nutrient cycling and primary production in the marine systems of the Arctic and Antarctic. Journal of Marine Systems 2:359-384.

COOPER, L.W., WHITLEDGE, T.E., and GREBMEIER, J.M. 1997. The nutrient, salinity and stable oxygen isotope composition of Bering and Chukchi Seas waters in and near the Bering Strait. Journal of Geophysical Research 102(C6):12563-12573.

COPPOLA, L., ROY-BARMAN, M., WASSMANN, P., and JEANDEL, C. 2002. Calibration of sediment traps and particulate organic carbon export using ${ }^{234} \mathrm{Th}$ in the Barents Sea. Marine Chemistry 80(1):11-26.

COTA, G.F., KOTTMEIER, S.T., ROBINSON, D.H., SMITH, W.O., Jr., and SULLIVAN, C.W. 1990. Bacterioplankton in the marginal ice zone of the Weddell Sea: Biomass, production and metabolic activities during austral autumn. Deep-Sea Research 37:1145-1167.

COTA, G.F., POMEROY, L.R., HARRISON, W.G., JONES, E.P., PETERS, F., SHELDON, W.M., and WEINGARTNER, T.R., Jr. 1996. Nutrients, primary production and microbial heterotrophy in the southeastern Chukchi Sea: Arctic summer nutrient depletion and heterotrophy. Marine Ecology Progress Series 135:247-258.

CUFFEY, K.M., ClOW, G.D., ALlEY, R.B., STUIVER, M., WADDINGTON, E.D., and SALTUS, R.W. 1995. Large Arctic temperature change at the Wisconsin-Holocene Glacial Transition. Science 270:455-458.

FUHRMAN, J.A., and AZAM, F. 1982. Thymidine incorporation as a measure of heterotrophic bacterioplankton production in marine surface waters: Evaluation and field results. Marine Biology 66:109-120.

GORDON, D.C., and CRANFORD, P.J. 1985. Detailed distribution of dissolved and particulate organic matter in the Arctic Ocean and comparison with other oceanic regions. Deep-Sea Research 32:1221-1232.

GUO, L., HUNG, C.C., SANTSCHI, P.H., and WALSH, I.D. 2002. ${ }^{234} \mathrm{Th}$ scavenging and its relationship to polysaccharide abundance in the Gulf of Mexico. Marine Chemistry 78:103-119.

JENKINS, W.J., and WALLACE, D.W.R. 1992. Tracer based inferences of new production in the sea. In: Falkowski, P.G., and Woodhead, A.D., eds. Primary productivity and biogeochemical cycles in the sea. Environmental Science Research, Vol. 43. New York: Plenum Press. 299-311.

JONES, E.P., and ANDERSON, L.G. 1986. On the origin of the properties of the Arctic Ocean halocline. Journal of Geophysical Research 91:10759-10767.

KIRCHMAN, D.L., KEIL, R.G., SIMON, M., and WELSCHME, N.A. 1993. Biomass and production of heterotrophic bacterioplankton in the oceanic subarctic Pacific. Deep-Sea Research 40:967-988.

KIRCHMAN, D.L., RICH, J.H., and BARBER, R.T. 1995. Biomass and biomass production of heterotrophic bacteria along $140^{\circ} \mathrm{W}$ in the equatorial Pacific: Effect of temperature on the microbial loop. Deep-Sea Research II 42:621-639.

KUPARINEN, J., and BJORNSEN, P.K. 1992. Spatial distribution of bacterioplankton production across the Weddell-Scotia 
Confluence during early austral summer 1988-1989. Polar Biology 12:197-204.

LEE, S., and FUHRMAN, J.A. 1987. Relationships between biovolume and biomass of naturally derived marine bacterioplankton. Applied and Environmental Microbiology 53:1298-1303.

LONGHURST, A., SATHYENDRANATH, S., PLATT, T., and CAVERHILL, C. 1995. An estimate of global primary production in the ocean from satellite radiometer data. Journal of Plankton Research 17:1245-1271.

MANABE, S., and STOUFFER, R.J. 1993. Century-scale effects of increased atmospheric $\mathrm{CO}_{2}$ on the ocean-atmosphere system. Nature 364:215-218.

MORAN, S.B., and BUESSELER, K.O. 1993. Size-fractionated ${ }^{234} \mathrm{Th}$ in continental shelf waters off New England: Implications for the role of colloids in oceanic trace metal scavenging. Journal of Marine Research 51:893-922.

MORAN, S.B., and SMITH, J.N. 2000. ${ }^{234}$ Th as a tracer of scavenging and particle export in the Beaufort Sea. Continental Shelf Research 20:153-167.

MORAN, S.B., ELLIS, K.M., and SMITH, J.N. 1996. ${ }^{234} \mathrm{Th} /{ }^{238} \mathrm{U}$ disequilibrium in the central Arctic Ocean. Radioprotection 32:169-175.

. 1997. ${ }^{234} \mathrm{Th} /{ }^{238} \mathrm{U}$ disequilibrium in the central Arctic Ocean: Implications for particulate organic carbon export. Deep-Sea Research II 44:1593-1606.

MURRAY, J.W., DOWNS, J.N., STROM, S., WEI C.-L., and JANNASCH, H.W. 1989. Nutrient assimilation, export production and ${ }^{234} \mathrm{Th}$ scavenging in the eastern equatorial Pacific. Deep-Sea Research 36:1471-1489.

MURRAY, J.W., YOUNG, J., NEWTON, J., DUNNE, J., CHAPIN, T., and PAUL, B. 1996. Export flux of particulate organic carbon from the central Equatorial Pacific determined using a combined drifting trap- ${ }^{234} \mathrm{Th}$ approach. Deep-Sea Research 43:1095-1132.
PARSONS, T.R., MAITA, Y., and LALLI, C.M. 1984. A manual of chemical and biological methods for seawater analysis. New York: Pergamon Press.

RICH, J., GOSSELIN, M., SHERR, E., SHERR, B., and KIRCHMAN, L. 1997. High bacterial production, uptake and concentrations of dissolved organic matter in the Central Arctic Ocean. Deep-Sea Research II 44:1645-1663.

RUTGERS VAN DER LOEFF, M.M., MICHEL, A., KEY, R. M., SCHOLTEN, J., and BAUCH, D. 1995. ${ }^{228} \mathrm{Ra}$ as a tracer for shelf water in the Arctic Ocean. Deep-Sea Research II 42:15331553.

RUTGERS VAN DER LOEFF, M.M., FRIEDRICH, J., and BATHMANN, U.V. 1997. Carbon export during the spring bloom at the southern polar front, determined with the natural tracer ${ }^{234} \mathrm{Th}$. Deep-Sea Research II 44:457-478.

SANTSCHI, P.H., GUO, L., QUIGLEY, M.S., BASKARAN, M., and WALSH, I. 1999. Boundary exchange and scavenging of radionuclides in continental margin waters of the Middle Atlantic Bight: Implications for organic carbon fluxes. Continental Shelf Research 19:609-636.

SCHLOSSER, P., SWIFT, J.H., LEWIS, D., and PFIRMAN, S.L. 1995. The role of the large-scale Arctic Ocean circulation in the transport of contaminants. Deep-Sea Research II 42: $1341-1367$.

SHIMMIELD, G.B., and RITCHIE, G.R. 1995. The impact of marginal ice zone processes on the distribution of ${ }^{210} \mathrm{~Pb},{ }^{210} \mathrm{Po}$ and ${ }^{234} \mathrm{Th}$ and implications for new production in the Bellingshausen Sea, Antarctica. Deep-Sea Research II 42: $1313-1335$.

SMITH, W.O., Jr., CODISPOTI, L.A., NELSON, D.M., MANLEY, T., BUSKEY, E.J., NIEBAUER, H.J., and COTA, G.F. 1991. Importance of Phaeocystis blooms in the high-latitude ocean carbon cycle. Nature 352:514-516.

WHEELER, P.A., GOSSELIN, M., SHERR, E., THIBAULT, D., KIRCHMAN, D.L., BENNER, R., and WHITLEDGE, T.E. 1996. Active cycling of organic carbon in the central Arctic Ocean. Nature 380:697-699. 